Marquette University

e-Publications@Marquette

Biological Sciences Faculty Research and

Publications

Biological Sciences, Department of

$10-2009$

\title{
Differences in leaf traits, leaf internal structure, and spectral reflectance between two communities of lianas and trees: Implications for remote sensing in tropical environments
}

\author{
G. Arturo Sanchez-Azofeifa \\ University of Alberta -Edmunton \\ Karen Castro \\ University of Alberta - Edmonton \\ S. Joseph Wright \\ Smithsonian Tropical Research Institute \\ John Gamon \\ University of Alberta - Edmonton \\ Margaret Kalacska \\ McGill University
}

See next page for additional authors

Follow this and additional works at: https://epublications.marquette.edu/bio_fac

Part of the Biology Commons

\section{Recommended Citation}

Sanchez-Azofeifa, G. Arturo; Castro, Karen; Wright, S. Joseph; Gamon, John; Kalacska, Margaret; Rivard, Benoit; Schnitzer, Stefan A.; and Feng, Ji Lu, "Differences in leaf traits, leaf internal structure, and spectral reflectance between two communities of lianas and trees: Implications for remote sensing in tropical environments" (2009). Biological Sciences Faculty Research and Publications. 708.

https://epublications.marquette.edu/bio_fac/708 


\section{Authors}

G. Arturo Sanchez-Azofeifa, Karen Castro, S. Joseph Wright, John Gamon, Margaret Kalacska, Benoit Rivard, Stefan A. Schnitzer, and Ji Lu Feng

This article is available at e-Publications@Marquette: https://epublications.marquette.edu/bio_fac/708 
Marquette University

e-Publications@Marquette

\title{
Biology Faculty Research and Publications/College of Arts and Sciences
}

This paper is NOT THE PUBLISHED VERSION; but the author's final, peer-reviewed manuscript. The

published version may be accessed by following the link in the citation below.

Remote Sensing of Environnent, Vol. 113, No. 10 (October 2009): 2076-2088. DOI. This article is (C) Elsevier and permission has been granted for this version to appear in e-Publications@Marquette. Elsevier does not grant permission for this article to be further copied/distributed or hosted elsewhere without the express permission from Elsevier.

\section{Differences in leaf traits, leaf internal structure, and spectral reflectance between two communities of lianas and trees: Implications for remote sensing in tropical environments}

\author{
G. Arturo Sánchez- Azofeifa \\ Earth Observation Systems Laboratory (EOSL), Department of Earth and Atmospheric Sciences, University of \\ Alberta, Edmonton, Alberta, Canada \\ Smithsonian Tropical Research Institute (STRI), Box 2072, Balboa, Ancon, Republic of Panama
}

Karen Castro

Earth Observation Systems Laboratory (EOSL), Department of Earth and Atmospheric Sciences, University of Alberta, Edmonton, Alberta, Canada

S. Joseph Wright

Smithsonian Tropical Research Institute (STRI), Box 2072, Balboa, Ancon, Republic of Panama John Gamon

Earth Observation Systems Laboratory (EOSL), Department of Earth and Atmospheric Sciences, University of Alberta, Edmonton, Alberta, Canada 


\section{Margaret Kalacska}

Department of Geography, McGill University, 805 Sherbrooke St. West, Montreal, QC, Canada

\section{Benoit Rivard}

Earth Observation Systems Laboratory (EOSL), Department of Earth and Atmospheric Sciences, University of Alberta, Edmonton, Alberta, Canada

\section{Stefan A. Schnitzer}

Smithsonian Tropical Research Institute (STRI), Box 2072, Balboa, Ancon, Republic of Panama

Department of Biological Sciences, University of Wisconsin- Milwaukee, PO Box 413, Milwaukee, WI

\section{Ji Lu Feng}

Earth Observation Systems Laboratory (EOSL), Department of Earth and Atmospheric Sciences, University of Alberta, Edmonton, Alberta, Canada

\section{Abstract}

Increasing dominance of lianas in many tropical forests is considered a fingerprint of global environmental change. Despite the key role they play in ecosystem functioning, lianas remain one of the least studied life forms in tropical environments. This paper contrasts leaf traits and spectral properties $(400-1100 \mathrm{~nm})$ of liana and tree communities from a tropical dry forest and a tropical rainforest in Panama, Central America. Differences between lianas and tree leaf traits were analyzed using spectroscopy, leaf histology and pigment extractions. Results from this study indicate that many of the biochemical, structural, and optical properties of lianas and trees are different in the dry forest site but not in rainforest sites. In the dry forest site, liana leaves exhibited significantly lower chlorophyll and carotenoid contents and were thinner than the leaves of their host trees. Specific leaf area, dry to fresh mass ratio, and mean water content of liana leaves were significantly higher when compared with tree leaves. The differences observed in the tropical dry forest site indicate that lianas may have a higher rate of resource acquisition and usage, whereas trees tend to conserve acquired resources. We suggest that our results may be indicative of the presence of a liana syndrome related to water availability and thus best exhibited in tropical dry forests. Our findings have important implications for using remote sensing to accurately map the distribution of liana communities at regional scales and for the continued expansion of lianas in tropical environments as a result of global change.

\section{Keywords}

Tropical dry forests, Tropical rainforest, Spectroscopy, Liana leaves, Tree leaves, Pigment concentration, Internal leaf structure, Hyperspectral remote sensing

\section{Introduction}

Tropical forest research using hyperspectral data is currently in its early stages of development. Progress has been constrained by limited access to hyperspectral data, limited access to the top of tall tropical forest canopies to provide field validation, and by the greater complexity of tropical forests as compared to temperate and boreal regions. Basic research in tropical environments on the quantification of pigments, photo-protective mechanisms as a function of different life forms, light scattering mechanisms at surface and cellular levels, or the impact of endophytes, epiphylls and galls on the spectral reflectance of leaves and canopies is, in addition, almost non-existent. Some exceptions are Lee and Graham (1986) and Lee et al. (1990) who reported correlations between leaf optical properties of sun vs. shade leaves on a set of tree species from Costa Rica, Panama and the United States; Roberts et al. (1998), who reported the impact of leaf age on the spectral properties of tree species from the Amazon caatinga, Cochrane (2000) who explored the potential separability 
of Amazonian mahogany from selected background species, and Clark et al. (2005) who explore the separability between a selected number of tree species at La Selva Biological Station, Costa Rica. Zhang et al.

(2006) documented the intra and inter-species variability of spectral reflectance for tree species of Mesoamérica while Castro-Esau et al. (2006) examined specific factors controlling their spectral variability. Gamon et al.

(2005) documented contrasting photo-protective strategies among trees within a single Panamanian dry forest stand. These strategies, which ranged from photosynthetic downregulation to leaf movement and leaf shedding, were all detectable with spectral reflectance, indicating the potential for remote detection of contrasting physiological function.

A unique characteristic of tropical forests is the density of species for a given area. Gentry (1991) reports a range of 21-121 tree species for various 0.1 ha plots around the Neotropics. Lianas are woody climbers that further increase canopy plant diversity. Lianas play a key role in the community structure and ecosystem function of tropical dry and rainforests. In particular, lianas suppress tree regeneration and promote tree mortality (Laurence et al., 2001). Studies of the dynamics of liana coverage in tropical environments indicate high percentages of tree infestation for many parts of the neotropics. Examples from the Neotropics include $43 \%$ of trees at Rio Negro, Venezuela; $47 \%$ at Barro Colorado Island, Panama; 63\% at Los Tuxtlas, Mexico; $73 \%$ at La Chonta, Bolivia; and 86\% at Oquirita, Boliva (Putz, 1983, Putz, 1984, Alvira et al., 2004, Pérez-Salicrup et al., 2001, Pérez-Salicrup and de Meijere, 2005). Lianas are one of the least studied life forms in tropical forests even though their dominance is growing relative to trees in many tropical forests (Phillips et al., 2002, Phillips et al., 2005, Wright et al., 2004) and they are considered to be one of the ten key fingerprints of global environmental change in tropical environments (Phillips et al., 2002).

Information on the optical properties of lianas and their controlling mechanisms is even more limited. Avalos et al. (1999) documented differences in absorbance and transmittance between lianas and trees from a tropical dry forest (Parque Natural Metropolitano, Panama). They examined leaf optical properties of 12 liana and 7 tree species during the rainy season and found differences among life forms for transmittance but not for absorbance and reflectance. Castro-Esau et al. (2004) explored the separability of liana and tree leaves using hyperspectral signatures collected during the dry season and reported that the two life forms were distinct at a dry forest site (Parque Natural Metropolitano, Panama) but not at a rainforest site (Fort Sherman, Panama). More recently, Sánchez-Azofeifa and Castro-Esau (2006) and Kalácska et al. (2007) have documented differences between spectral reflectance at the leaf and crown levels at liana infested sites. Because lianas may obscure or distort the optical signals of trees, it is imperative to determine the differences in leaf-level characteristics of lianas and trees in tropical forests, and to test whether these differences are reflected in their leaf and canopy optical properties. Furthermore, determining the leaf-level attributes of lianas may shed light on their competitive strategies (Wright et al., 2001, Reich et al., 1998), which may explain their relative increase in abundance in tropical and temperate forests (Phillips et al., 2002, Wright et al., 2004, Wright and Calderón, 2006, Mohan et al., 2006).

In this paper we seek the answers to three questions: 1) Do leaf pigment concentrations and spectral reflectance differ between life forms? 2) Do leaf internal structure and near-infrared reflectance differ between life forms? and 3) Do leaf traits such as Specific Leaf Area (SLA), leaf thickness, water content, and nitrogen (N) and phosphorus $(P)$ concentration differ between life forms? We explored these questions in the context of spectral reflectance measured between 400 and $1100 \mathrm{~nm}$. This work expands previous studies by Castro-Esau et al. (2004) and Kalácska et al. (2007) who explored the use of advanced parametric and non-parametric classification approaches to evaluate the spectral separability between lianas and trees at the same sites, but without exploring in-depth the biochemical and structural drivers that contribute to such separability. 


\section{Materials and methods}

\subsection{Study area}

Leaf samples were collected using two canopy cranes maintained by the Smithsonian Tropical Research Institute (STRI) in Panama. Samples were collected at the Parque Natural Metropolitano (PNM), located near the Pacific coast, and the Parque Nacional San Lorenzo (FS; Fort Sherman) located near the Caribbean coast. At PNM, annual rainfall averages $1740 \mathrm{~mm}$, a severe dry season extends from mid-December to the end of April, and the vegetation is 80-100 year old, 30-m tall tropical dry forest. At FS, annual rainfall averages $3300 \mathrm{~mm}$, a mild dry season extends from January through March, and the vegetation is 200-300 year old tropical rainforest. The canopy cranes in both sites allow flexible access to the upper forest canopy via a gondola from which it is possible to collect leaf samples by hand at both sites (Parker et al., 1992, Castro-Esau et al., 2004).

\subsection{Leaf sample collection}

Samples were collected during the rainy season (August 2004). Sun leaves were collected from ten different individuals of the more abundant species present within the reach of the crane arm, following sampling protocols defined by Castro-Esau et al., 2004, Castro-Esau et al., 2006 and Kalácska et al. (2007). A total of 26 species of lianas and 9 species of trees were sampled from PNM; 9 species of lianas and 9 species of trees were sampled from FS (Table 1). All sampled leaves were clear of epiphytes, mosses and galls. The total number of leaves collected per species (10) was the maximum approved by the Panamanian National Environment Authority (ANAM). Samples were immediately placed in sealable plastic bags with moistened paper towels; these bags were then placed in a larger black plastic bag containing ice. The length of time between sample collection and sample measurements depended on the type of analysis performed. These times are specified

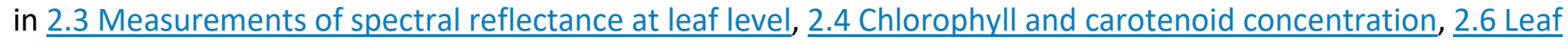
thickness, percentage water content, nitrogen/phosphorus and specific leaf area.

Table 1. List of species collected and analyzed at Parque Natural Metropolitano (dry forest) and Fort Sherman (rainforest) of Panama.

\begin{tabular}{|c|c|c|c|c|c|}
\hline Dry forest & & & Rainforest & & \\
\hline Family & Species & $\begin{array}{l}\text { Life } \\
\text { form }\end{array}$ & Family & Species & $\begin{array}{l}\text { Life } \\
\text { form }\end{array}$ \\
\hline Apocynaceae & Forsteronia spicata & $\mathrm{L}$ & Apocynaceae & $\begin{array}{l}\text { Odontadenia } \\
\text { puncticulosa }\end{array}$ & $\bar{L}$ \\
\hline Aristolochiaceae & Aristolochia maxima & $\mathrm{L}$ & Apocynaceae & $\begin{array}{l}\text { Fosteronia } \\
\text { myriantha }\end{array}$ & $\mathrm{L}$ \\
\hline Asteraceae & Mikania leiostachya & $\mathrm{L}$ & Bignoniaceae & $\begin{array}{l}\text { Arrabidaea } \\
\text { verrucosa }\end{array}$ & $\mathrm{L}$ \\
\hline Bignoniaceae & $\begin{array}{l}\text { Amphilophium } \\
\text { paniculatum }\end{array}$ & $\mathrm{L}$ & Bignoniaceae & $\begin{array}{l}\text { Pleonotoma } \\
\text { variabilis }\end{array}$ & $\bar{L}$ \\
\hline Bignoniaceae & $\begin{array}{l}\text { Pithecoctenium } \\
\text { crucigerum }\end{array}$ & $\mathrm{L}$ & Convolvulaceae & $\begin{array}{l}\text { Maripa } \\
\text { panamensis }\end{array}$ & $\bar{L}$ \\
\hline Bignoniaceae & Arrabidaea patellifera & $\mathrm{L}$ & Dilleniaceae & $\begin{array}{l}\text { Doliocarpus } \\
\text { multiflorus }\end{array}$ & $\bar{L}$ \\
\hline Bignoniaceae & Stizophyllum riparium & $\mathrm{L}$ & $\begin{array}{l}\text { Fabaceae- } \\
\text { Papilionoideae }\end{array}$ & Dioclea wilsonii & $\bar{L}$ \\
\hline Bignoniaceae & $\begin{array}{l}\text { Phryganocydia } \\
\text { corymbosa }\end{array}$ & $\mathrm{L}$ & Hippocrateaceae & $\begin{array}{l}\text { Tontelea } \\
\text { ovalifolia }\end{array}$ & $\bar{L}$ \\
\hline Bignoniaceae & Arrabidaea candicans & $\mathrm{L}$ & Hippocrateaceae & Unknown sp. & $\mathrm{L}$ \\
\hline Convolvulaceae & Bonamia trichantha & $\mathrm{L}$ & Apocynaceae & $\begin{array}{l}\text { Aspidosperma } \\
\text { cruenta }\end{array}$ & $T$ \\
\hline
\end{tabular}




\begin{tabular}{|c|c|c|c|c|c|}
\hline Convolvulaceae & Jacquemontia perryana & $\mathrm{L}$ & Boraginaceae & Cordia bicolor & $\mathrm{T}$ \\
\hline Dilleniaceae & Doliocarpus major & $\mathrm{L}$ & $\begin{array}{l}\text { Fabaceae- } \\
\text { Papilionoideae }\end{array}$ & $\begin{array}{l}\text { Lonchocarpus } \\
\text { longifolium }\end{array}$ & $\mathrm{T}$ \\
\hline Dilleniaceae & Doliocarpus dentatus & $\mathrm{L}$ & Meliaceae & $\begin{array}{l}\text { Carapa } \\
\text { guianensis }\end{array}$ & $T$ \\
\hline Dilleniaceae & Tetracera portobellensis & $\mathrm{L}$ & Moraceae & Brosimum utile & $\mathrm{T}$ \\
\hline $\begin{array}{l}\text { Fabaceae- } \\
\text { Papilionoideae }\end{array}$ & Machaerium milleflorum & $\mathrm{L}$ & Moraceae & $\begin{array}{l}\text { Ficus } \\
\text { nymphaeifolia }\end{array}$ & $T$ \\
\hline Hippocrateaceae & Prionostema aspera & $\mathrm{L}$ & Sapindaceae & Matayba apetala & $\mathrm{T}$ \\
\hline $\begin{array}{l}\text { Fabaceae- } \\
\text { Papilionoideae }\end{array}$ & Machaerium riparium & $\mathrm{L}$ & Sapotaceae & $\begin{array}{l}\text { Manilkara } \\
\text { bidentata }\end{array}$ & $\mathrm{T}$ \\
\hline Hippocrateaceae & Hippocratea volubilis & $\mathrm{L}$ & Sapotaceae & $\begin{array}{l}\text { Pouteria } \\
\text { reticulate }\end{array}$ & $\mathrm{T}$ \\
\hline Malpighiaceae & Hiraea reclinata & $\mathrm{L}$ & & & \\
\hline Malpighiaceae & $\begin{array}{l}\text { Stigmaphyllon } \\
\text { hypargyreum }\end{array}$ & $\mathrm{L}$ & & & \\
\hline Passifloraceae & Passiflora vitifolia & $\mathrm{L}$ & & & \\
\hline Phytolaccaceae & Trichostigma octandrum & $\mathrm{L}$ & & & \\
\hline Rhamnaceae & Gouania lupuloides & $\mathrm{L}$ & & & \\
\hline Sapindaceae & Serjania mexicana & $\mathrm{L}$ & & & \\
\hline Sapindaceae & Serjana atrolineata & $\mathrm{L}$ & & & \\
\hline Vitaceae & Vitis tiliifolia & $\mathrm{L}$ & & & \\
\hline Anacardiaceae & Anacardium excelsum & $\mathrm{T}$ & & & \\
\hline Anacardiaceae & Astronium graveolens & $\mathrm{T}$ & & & \\
\hline Annonaceae & Annona spraguei & $\mathrm{T}$ & & & \\
\hline Bombacaceae & $\begin{array}{l}\text { Pseudobombax } \\
\text { septenatum }\end{array}$ & $T$ & & & \\
\hline Boraginaceae & Cordia alliodora & $\mathrm{T}$ & & & \\
\hline Moraceae & Ficus insipida & $\mathrm{T}$ & & & \\
\hline Moraceae & Castilla elastica & $\mathrm{T}$ & & & \\
\hline Sapotaceae & $\begin{array}{l}\text { Chrysophyllum } \\
\text { argenteum }\end{array}$ & $T$ & & & \\
\hline Tiliaceae & Luehea seemannii & $\mathrm{T}$ & & & \\
\hline
\end{tabular}

\subsection{Measurements of spectral reflectance at leaf level}

Spectral reflectance measurements (400 to $1100 \mathrm{~nm}$ ) of leaves were taken the same day as collection. Research by Foley et al. (2006) indicates that spectral reflectance features characteristic of leaf structure, bulk pigment pool sizes or water content do not vary significantly within this time frame, so long as leaf moisture content is maintained. We note that these sampling methods cannot resolve more dynamic changes due to rapid photochemical regulatory processes (detectable as fluorescence or xanthophyll cycle pigment conversion), which require non-destructive, in situ sampling approaches (e.g. Gamon et al., 1997). Spectral measurements were conducted using a portable spectrometer (Unispect, PPSystems, Amesbury, MA, USA) sampling a $2.57 \mathrm{~cm}^{2}$ leaf core. The spectrometer was fitted with a bifurcated fiber optic and a leaf clip $\left(3.46 \mathrm{~mm}^{2}\right.$ sampling area) and reported visible/near infrared spectral reflectance $(400-1100 \mathrm{~nm})$ with a spectral resolution $<10 \mathrm{~nm}$, and absolute wavelength accuracy $<0.3 \mathrm{~nm}$. Leaf cores were then wrapped in aluminum foil and frozen for later pigment analysis (Section 2.4). In addition to these spectral reflectance measurements, diffuse transmittance $(T T)$ and reflectance (RR) were measured for five mature leaves per species using a barium-sulfate-coated integrating sphere with it own light source (LICOR 1800-12S, Lincoln, NE, USA) connected to the spectrometer (UniSpec, PPSystems, Amesbury, MA, USA,). Absorptance (AA) was estimated as the complement of reflectance 
plus transmittance $(A A=1-(T T+R R)$. Absorptance, transmittance and reflectance data was then aggregated for each structural group level for further analyses.

\subsection{Chlorophyll and carotenoid concentration}

Chlorophyll $a, b$, total chlorophyll, and carotenoid content were estimated using a dimethyl sulfoxide (DMSO) extract (Richardson et al., 2002) and a spectrophotometer (SMART Spectrometer, LaMotte Company, Chestertown, MD, USA) with a wavelength range of 300-1000 nm and a wavelength resolution of $1 \mathrm{~nm}$ and accuracy of $2 \mathrm{~nm}$. Frozen samples were removed from the freezer, placed in a $10.0 \mathrm{ml}$ DMSO solution, and warmed using a pre-heated water bath to $65^{\circ} \mathrm{C}$ for $20 \mathrm{~min}$. Samples were then removed and allowed to cool. Once cooled, each sample ( $3 \mathrm{ml}$ ) was transferred using a disposable sample pipette, to a disposable cuvette. Absorbance at 447, 646 and $664 \mathrm{~nm}$ was measured. These wavelengths were selected upon calibration of the spectrophotometer using pure chlorophyll $a$ and $b$ extracts. Chlorophyll $a$, Chlorophyll $b$, total chlorophyll and carotenoid content were reported by unit area $\left(\mu \mathrm{mol} / \mathrm{m}^{2}\right)$.

\subsection{Leaf histology}

Leaf histological analysis was performed on 26 liana and 9 tree species sampled from the tropical Dry forest, and 9 liana and 9 tree species from the rainforest. Three mature leaves from different individuals per species were collected early morning from the crane, placed on dry ice, and transported to the University of Alberta confocal microscopy laboratory. Total time elapsed between collection and arrival at the laboratory was less than $24 \mathrm{~h}$. Once in the laboratory, three small strips measuring approximately $10 \mathrm{~mm}$ in length by $4 \mathrm{~mm}$ in width were cut from each leaf sample. Prominent leaf veins, especially the midrib, were avoided. The strips were later fixed in formalin aceto-alcohol and placed in a vacuum oven for two weeks under approximately - 15 psi. After two weeks, samples were run through an ethanol-processing center and transferred to a hot paraffin wax bath for embedding into paraffin rings.

For each sample, thin sections $(5 \mu \mathrm{m})$ were cut and mounted onto microscope slides. The slides were stained using a sequence of timed immersions in chemical baths containing Harris' hematoxylin and acid eosin. The thin sections were then photographed using a confocal microscope, with emphasis on areas with unbroken cell structure and good focus. Finally, images were cleaned of background noise surrounding the tissue cross-section and color-enhanced using image processing software (Photoshop 7.0, Adobe Systems, Inc., San Jose, CA, USA). A scale bar and a species name label were added to the final product. Final cross sections were analyzed in additional image processing software (ERDAS IMAGINE V. 9.4, Norcross, Georgia, USA) with an unsupervised classification. From the classified image, percentage of empty (air) spaces in the mesophyll layer was estimated for each sample and compared against reflectance at $800 \mathrm{~nm}\left(R_{800 \mathrm{~nm}}\right)$. Percentage of empty space is related to the number of interfaces between cell walls and empty space in the mesophyll at which light can be reflected, contributing to the overall near-infrared reflectance from the leaf (Gausman et al., 1969).

\subsection{Leaf thickness, percentage water content, nitrogen/phosphorus and specific leaf} area

Leaf thickness was measured for five mature, healthy leaves from different individuals per species. Average thickness per leaf was reported as the mean of six measurements taken from near the apex, middle and base using a leaf thickness micrometer (to nearest $0.001 \mathrm{~mm}$ ) (Nikon, Tokyo, Japan). These measurements were within $2 \mathrm{~h}$ of sample collection. In addition, leaf fresh and dry weight were determined, the latter after drying at $60{ }^{\circ} \mathrm{C}$ for $36 \mathrm{~h}$. Nitrogen (as \% mass) was estimated using a combustion elemental analyzer (Richards, 1993a). Phosphorus concentration (as \% mass) was estimated using digestion followed by colorimetric analysis (Richards, 1993b). Specific leaf area (SLA) was estimated as the ratio of fresh surface area to dry weight. 


\subsection{Spectral analyses}

Although we recognized that there are a significant number of spectral indices widely used in the remote sensing literature (see le Maire et al., 2004), our spectral analysis used two spectral indices of chlorophyll content (Sims \& Gamon, 2002), and two approaches to study linkages between water content and spectral reflectance. The two spectral chlorophyll indices used here have the strength of have been previously tested on different functional groups with positive results (Sims \& Gamon, 2002). Specifically we use the modified normal difference at $705 \mathrm{~nm}\left(\mathrm{mND}_{705}=\left(R_{750}-R_{705}\right) /\left(R_{750}+R_{705}-2 R_{445}\right)\right.$, and the modified simple ratio $\left(\mathrm{mSR}_{705}=\left(R_{750}-R_{445}\right) /\left(R_{705}\right)-R_{445}\right)$.

The relationship between water content and spectral reflectance was first explored using the $970 \mathrm{~nm}$ Water Band Index (WBI $\left.=R_{900} / R_{970}\right)$ defined by Penuelas et al. (1993). Secondly, as instrument noise have significant influences on the definition of the 960-970 nm water feature and therefore affects the WBI approach, we used a Gaussian filtering of the original spectra followed by continuum removal to measure of the above water absorption; and then a continuous wavelet analysis to extract the water feature by minimizing influences from noises and spectral continuum (Rivard et al., 2008).

Gaussian filtering has been used extensively to remove noise in signal processing (Shapiro and Stockman, 2001, Mark and Alberto, 2008). Removal of the spectral continuum is a routine approach in hyperspectral analysis to determine the relative band depth of a specific feature (Clark \& Roush, 1984). The definition of the spectral continuum and the feature location is much reliable on the smoothed spectrum rather than on the noisy original spectrum. This approach is more effective than regular mean filter in spectral smoothing because it uses a point-spread function that preserves better any spectral feature.

Spectral wavelet analysis has been used for extracting spectral features in the wavelet domain (Bruce and $\mathrm{Li}$, 2001, Bruce et al., 2006). Recent studies (Rivard et al., 2008) have proved that continuous wavelet analysis using a 2nd order Gaussian derivative are effective for noise reduction and continuum removal from spectral data when proper scales are selected for feature detection. The merit of the wavelet analysis falls on the need to better define the $960 \mathrm{~nm}-970 \mathrm{~nm}$ water absorption feature from the Unispec ${ }^{\circledR}$ data where the $\mathrm{S} / \mathrm{N}$ ratio is low and spectral continuum drops off dramatically.

Finally, we compared peak reflectance at $550 \mathrm{~nm}\left(R_{550 \mathrm{~nm}}\right)$ as an additional indicator of chlorophyll absorption, reflectance at $800 \mathrm{~nm}\left(R_{800 \mathrm{~nm}}\right)$ as an indicator of light scattering inside of the spongy mesophyll layer, and conduce an analysis on the reflectance at the red edge (Mohd-Shafri et al., 2006).

\subsection{Statistical analysis}

Descriptive statistics were calculated for all variables and compared for both study sites among life forms (Table 2). For the purpose of all analyses in this paper all liana and tree spectra were clustered on two different structural groups or life forms (lianas vs. trees) and no differences among specific species was explored. In addition, a difference among life forms at the site level (dry forest or rainforest separated) but not between sites (dry and rainforest together) was explored. Statistical analyses were calculated using a $t$-test (95\% confidence level, $\alpha=0.05$, two-tail, assumption of normality tested first at $\alpha=0.05$ ) after first performing a Levene's test to check the validity of the assumption of equal variances. The null hypothesis of no significant differences between the liana and tree species $\left(H_{0}: \mu_{\text {liana }}=\mu_{\text {tree}}\right)$ was evaluated. Comparisons across life forms and between sites were made with a two-way ANOVA.

Table 2. Summary of average chemical, leaf trait and spectral reflectanceproperties among lianas and trees from the Parque Natural Metropolitano (PNM-dry forest) and Fort Sherman (FS-rainforest).

\begin{tabular}{|c|c|c|c|c|c|c|c|c|}
\hline Variable & Dry & Dry & Dry & Dry & Rain & Rain & Rain & Rain \\
\hline & Lianas & Lianas & Trees & Trees & Lianas & Lianas & Trees & Trees \\
\hline
\end{tabular}




\begin{tabular}{|c|c|c|c|c|c|c|c|c|}
\hline & Mean & STDV & Mean & STDV & Mean & STDV & Mean & STDV \\
\hline $\begin{array}{l}\text { Chlorophyll (micro- } \\
\mathrm{mol} / \mathrm{m}^{2} \text { ) }\end{array}$ & 385.6 & 84.6 & 523.7 aㅡ & 192.88 & 423.4 & 174.8 & 369.8 & 146.6 \\
\hline $\begin{array}{l}\text { Carotenoid (micro- } \\
\mathrm{mol} / \mathrm{m}^{2} \text { ) }\end{array}$ & $170.2^{a}$ & 47.8 & 237.7 a & 108.5 & 165.5 & 74.1 & 183.2 & 67.2 \\
\hline Water content (\%) & 64.6 & 9.45 & 55.6 & 4.24 & $61.6 \underline{b}$ & 5.35 & $54.7 \underline{b}$ & 6.45 \\
\hline Leaf thickness (mm) & $0.25 \underline{a}$ & 0.06 & $0.30^{a}$ & 0.08 & 0.28 & 0.05 & $0.30 \underline{\underline{b}}$ & 0.08 \\
\hline $\begin{array}{l}\text { Air spaces mesophyll } \\
\text { (\%) }\end{array}$ & 18.9 & 9.8 & 13.6 & 7.6 & 13.0 & 8.4 & 14.7 & 8.1 \\
\hline $\operatorname{SLA}\left(\mathrm{m}^{2} / \mathrm{kg}\right)$ & $14.55^{a}$ & 6.55 & $10.49 a$ & 4.24 & 9.44 & 2.55 & 7.29 & 1.74 \\
\hline Nitrogen (\%) & 2.41 & 0.676 & 2.14 & 0.356 & 2.0 & 0.485 & 1.83 & 0.317 \\
\hline Phosphorous (\%) & 0.164 & 0.070 & 0.136 & 0.020 & 0.0968 & 0.027 & 0.0859 & 0.017 \\
\hline Dry mass : fresh mass & $0.341^{a}$ & 0.0822 & $0.419 a$ & 0.0604 & 0.471 & 0.049 & 0.477 & 0.0384 \\
\hline$R_{550 \mathrm{~nm}}$ & 0.126 a & 0.028 & $0.087 \geqq$ & 0.013 & 0.11 & 0.037 & 0.11 & 0.028 \\
\hline$R_{800 \mathrm{~nm}}$ & 0.557 & 0.055 & 0.539 & 0.071 & 0.553 & 0.052 & 0.553 & 0.045 \\
\hline $\mathrm{mSR}_{705}$ & $3.12 a$ & 0.61 & $3.99 a$ & 0.41 & 3.06 & 0.99 & 2.35 & 1.53 \\
\hline $\mathrm{mND}_{705}$ & $0.50 a$ & 0.07 & $0.60 a$ & 0.03 & 0.51 & 0.09 & 0.46 & 0.12 \\
\hline $\mathrm{WBI}_{970}$ & 1.028 & 0.020 & 1.026 & 0.025 & 1.014 & 0.010 & 1.016 & 0.022 \\
\hline Red edge & $0.3201 \mathrm{a}$ & 0.072 & 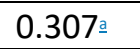 & 0.037 & 0.343 & 0.051 & 0.338 & 0.043 \\
\hline $\begin{array}{l}\text { Cont-removal } \\
\text { reflectance }\end{array}$ & 0.996 & 0.0021 & 0.997 & 0.0024 & 0.998 & 0.0017 & 0.996 & .0023 \\
\hline Cont-removal depth & 0.0038 & 0.0021 & 0.0030 & 0.0024 & 0.0034 & 0.0017 & 0.0035 & 0.0023 \\
\hline Wavelet power & -.00154 & 0.0021 & -.0001 & 0.0034 & -.0008 & .0020 & -.0007 & 0.0026 \\
\hline
\end{tabular}

aDenotes a highly significant statistical difference among the two structural groups $(p<0.001)$.

bDenotes significant difference $(p<0.01)$; numbers without a symbol reflect no statistically significant difference among the structural groups.

We selected the Bhattacharyya distance measure (Eqs. (1), (2)) as a tool to identify the wavelengths with the greatest discriminatory power between the reflectance spectra of lianas and trees across the 400-1100 nm wavelength range. The Bhattacharyya test statistic $(B)$ is used as a class separability measure to minimize classification error by providing a bound of classification accuracy (Landgrebe, 2003, Richards, 2005). The first term of $B$ (Eq. (1)) is the mean difference and the second term the covariance difference. The first term of the Bhattacharyya distance is also associated to the Mahalanobis distance (Mahalanobis, 1936).

(1) $B=\frac{1}{8}\left[\mu_{f}-\mu_{g}\right]^{T}\left[\frac{\Sigma_{f}+\Sigma_{g}}{2}\right]^{-1}\left[\mu_{f}-\mu_{g}\right]+\frac{1}{2} \ln \frac{\left|\frac{1}{2}\left[\Sigma_{f}+\Sigma_{g}\right]\right|}{\sqrt{\left|\Sigma_{f}\right|\left|\Sigma_{g}\right|}}$

a more simplified form of $(B)$ that considers a multivariate Gaussian distribution (Bhattacharyya, 1943) can be written as:

(2) $B=1 / 8\left(\mu_{f}-\mu_{g}\right)^{T} P^{-1}\left(\mu_{f}-\mu_{g}\right)+1 / 2 \ln \left((\operatorname{det} P) /\left(\operatorname{det} P_{f} \operatorname{det} P_{g}\right)^{0.5}\right)$

where $\mu_{i}$ and $P_{i}$ are the means and covariances of the two distributions respectively, and $P$ is equal to $\left(\sum_{f}+\sum_{g}\right) / 2$.

As with any distance measure, there is no absolute correlation between classification accuracy and the value of the measure, however a higher value of the measure usually indicates a better classification accuracy. The Bhattacharyya measure is one of the few for which it is possible to derive the upper and lower bounds of the probability of correct classification (Landgrebe, 2003). In addition, this statistic often results in a nearly linear relationship between the value of the distance measure and the classification accuracy (Landgrebe, 2003). 


\section{Results}

3.1. Do leaf pigment concentrations and spectral reflectance differ between life forms?

Our results indicate that there were significant differences in pigment levels between lianas and trees at the dry forest site but not the rainforest site (Table 2). Lianas at the dry forest site had significantly lower chlorophyll concentration $(t=-4.102, p=0.000)$ and higher reflectance at $550 \mathrm{~nm}(t=7.298, p=0.000)$ relative to their host trees (Fig. 1a, Table 2). No significant differences were apparent in chlorophyll concentration $(t=1.443, p=0.076)$ and reflectance at $550 \mathrm{~nm}(t=1.238, p=0.219)$ for lianas and trees at the rainforest site (Table 2$)$. The two-way ANOVA identified a significant life form - forest type interaction $(p<0.0001)$ (Table 3 ).
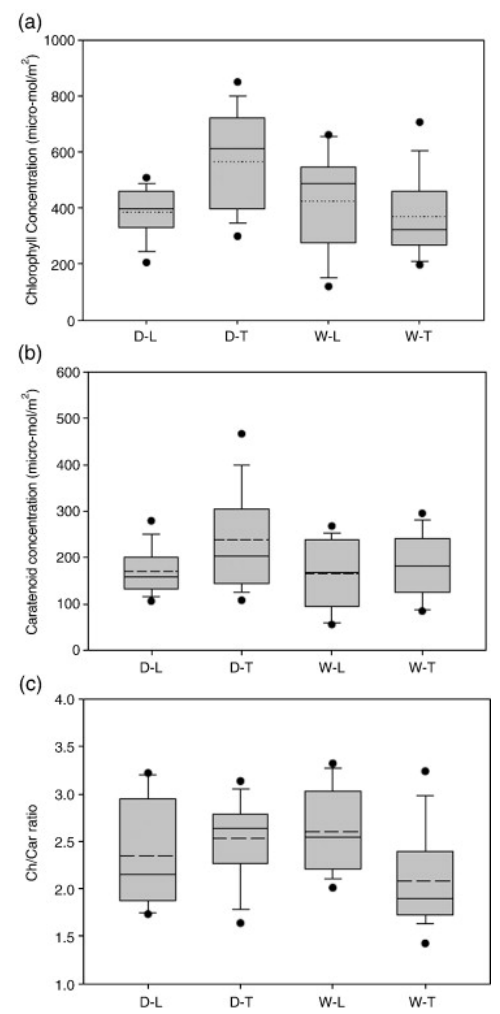

Fig. 1. Box plots for (a) total chlorophyll concentration, (b) carotenoidconcentration and (c) chlorophyll to carotenoid ratio for lianas (L) and trees (T) in a tropical dry (D) and rainforest (W). Dots outside of the box plot represent outliers and the $95 \%$ confidence level. Solid lines inside of the box represent outliers, solid lines represent the mean, dotted lines represent the median, the shaded area represents the 25th and 75th percentiles.

Table 3. Two-way ANOVA results for differences between lianas and tree leaves as function of site and life form.

\begin{tabular}{|l|l|l|l|}
\hline \multicolumn{1}{|c|}{ Variable } & \multicolumn{1}{c|}{$\boldsymbol{p}$} & \multicolumn{1}{c|}{$\boldsymbol{p}$} & \multicolumn{1}{c|}{$\boldsymbol{p}$} \\
\hline & \multicolumn{1}{|c|}{ (Life form) } & \multicolumn{1}{c|}{ (Location) } & \multicolumn{1}{c|}{ (Life form x Location) } \\
\hline Chlorophyll $\left(\mu \mathrm{mol} / \mathrm{m}^{2}\right)$ & 0.002 & 0.011 & $<0.0001$ \\
\hline Carotenoid $\left(\mu \mathrm{mol} / \mathrm{m}^{2}\right)$ & 0.001 & 0.197 & 0.049 \\
\hline Water content $(\%)$ & $<0.0001$ & 0.445 & 0.7715 \\
\hline Leaf thickness $(\mathrm{mm})$ & $<0.0001$ & $<0.0001$ & 0.2743 \\
\hline Air spaces mesophyll $(\%)$ & 0.415 & 0.541 & 0.236 \\
\hline SLA $\left(\mathrm{m}^{2} / \mathrm{kg}\right)$ & $<0.0001$ & $<0.0001$ & $<0.0001$ \\
\hline Nitrogen $(\%)$ & 0.266 & 0.069 & 0.805 \\
\hline Phosphorous $(\%)$ & 0.305 & 0.003 & 0.658 \\
\hline
\end{tabular}




\begin{tabular}{|l|l|l|l|}
\hline Dry mass: fresh mass & $<0.0001$ a & $<0.0001$ a & 0.0001 a \\
\hline$R_{550 n m}$ & $<0.0001$ & 0.367 & 0.001 \\
\hline$R_{800 n m}$ & 0.246 & 0.559 & 0.2399 \\
\hline $\mathrm{mSR}_{705}$ & $<0.0001$ a & 0.009 a & $<0.0001$ \\
\hline $\mathrm{mND}_{705}$ & $<0.0001$ & 0.040 & 0.0002 \\
\hline
\end{tabular}

No analyses were conducted for the $\mathrm{WBI}_{90}$ given that no statistical differences were observed between structural groups at any site or among sites.

aDenotes significant difference $(p<0.05)$; numbers without a symbol reflect no statistically significant difference among the structural groups.

Highly statistically significant differences in carotenoid concentration were also observed between lianas and trees from the tropical dry forest site $(t=-3.512, p=0.0005$, Fig. 1b) while no statistically significant differences were observed at the rainforest site $(t=-1.077, p=0.140)$. A significant life form - forest type interaction was found for carotenoid concentration $(p=0.049)$. Trees in the dry forest site also have a higher variability in carotenoid concentration. Similar results were also observed for the chlorophyll:carotenoid ratio (Fig. 1c).

Significant relationships exist between total chlorophyll content and the two spectral vegetation indices used in this paper ( $\mathrm{mND}_{705}$ and $\mathrm{mSR}_{705}$ ). Differences between life forms for both chlorophyll indices $\mathrm{mND}_{705}$ and $\mathrm{mSR}_{705}$ were observed only at the dry forest site (Fig. 2a and b, Table 2). For these life forms, two different correlations between these indices and chlorophyll content were observed for the dry forest sites (mND: lianas $r^{2}=0.317$, slope $=0.068$, trees: $r^{2}=0.306$, slope $=0.149$; mSR: lianas: $r^{2}=0.285$, slope $=0.0027$, trees: $r^{2}=0.026$, slope $=0.0027$ ), but not for the rainforest site (mND: lianas $r^{2}=0.359$, slope $=2 \times 10^{-4}$, trees: $r^{2}=0.264$, slope $=2 \times 10^{-4} ; \mathrm{mSR}$ : lianas: $r^{2}=0.341$, slope $=0.0018$, trees: $r^{2}=0.0270$, slope $=0.0018$ ), where a single correlation emerged ( $\underline{\text { Fig. 3 }}$ ). Similar results were present for the red edge analysis (ig. $4 \mathrm{a}$ and b). For the two life forms at the dry forest site two distinct regressions can be defined between chlorophyll content and the red edge reflectance (lianas $r^{2}=0.0046$, slope $=1 \times 10^{-5}$, trees: $r^{2}=0.063$, slope $=2 \times 10^{-4}$ ), but not at the rainforest site (lianas $r^{2}=0.3129$, slope $=-1 \times 10^{-4}$, trees: $r^{2}=0.5323$, slope $=-2 \times 10^{-4}$ ). Limited differences between the two life forms at the rainforest site are consistent with Castro-Esau et al. (2004), whose usedmachine learning classifiers to show that reflectance spectra of lianas and trees from tropical rainforests were not clearly separable in the 400-1100 nm range. 

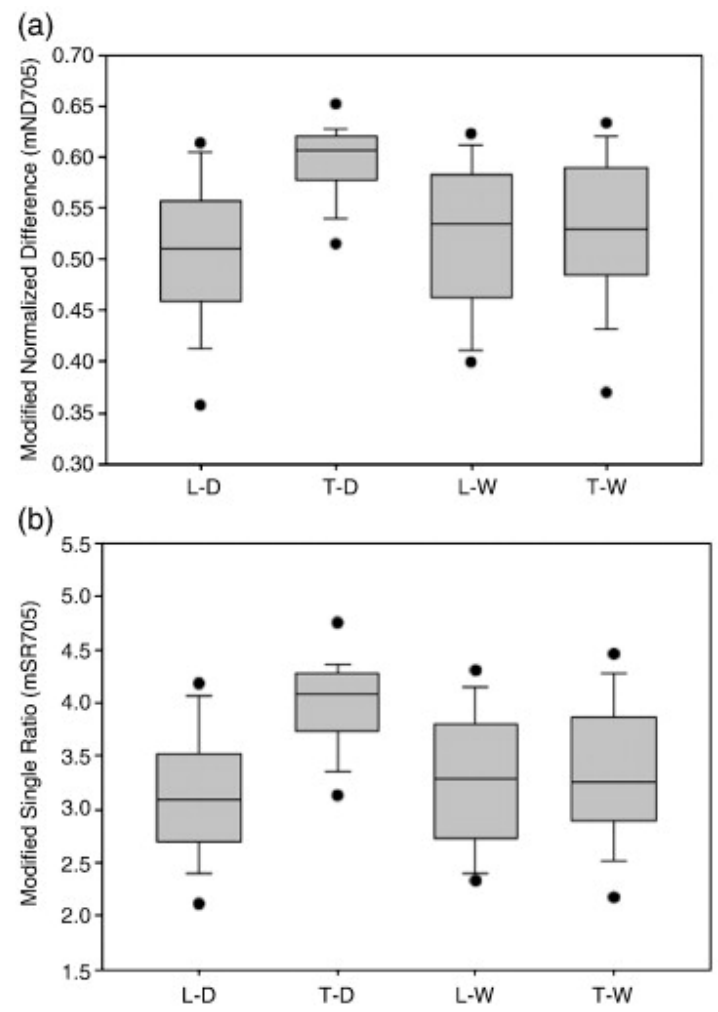

Fig. 2. Box plots for (a) Modified Normalized Difference (mND705) and (b) Modified Simple Ratio (mSR) (Table 2) for lianas $(L)$ and trees $(T)$ in a tropical dry $(D)$ and rainforest $(W)$. Lianas and trees can be distinguished for the dry forest only.
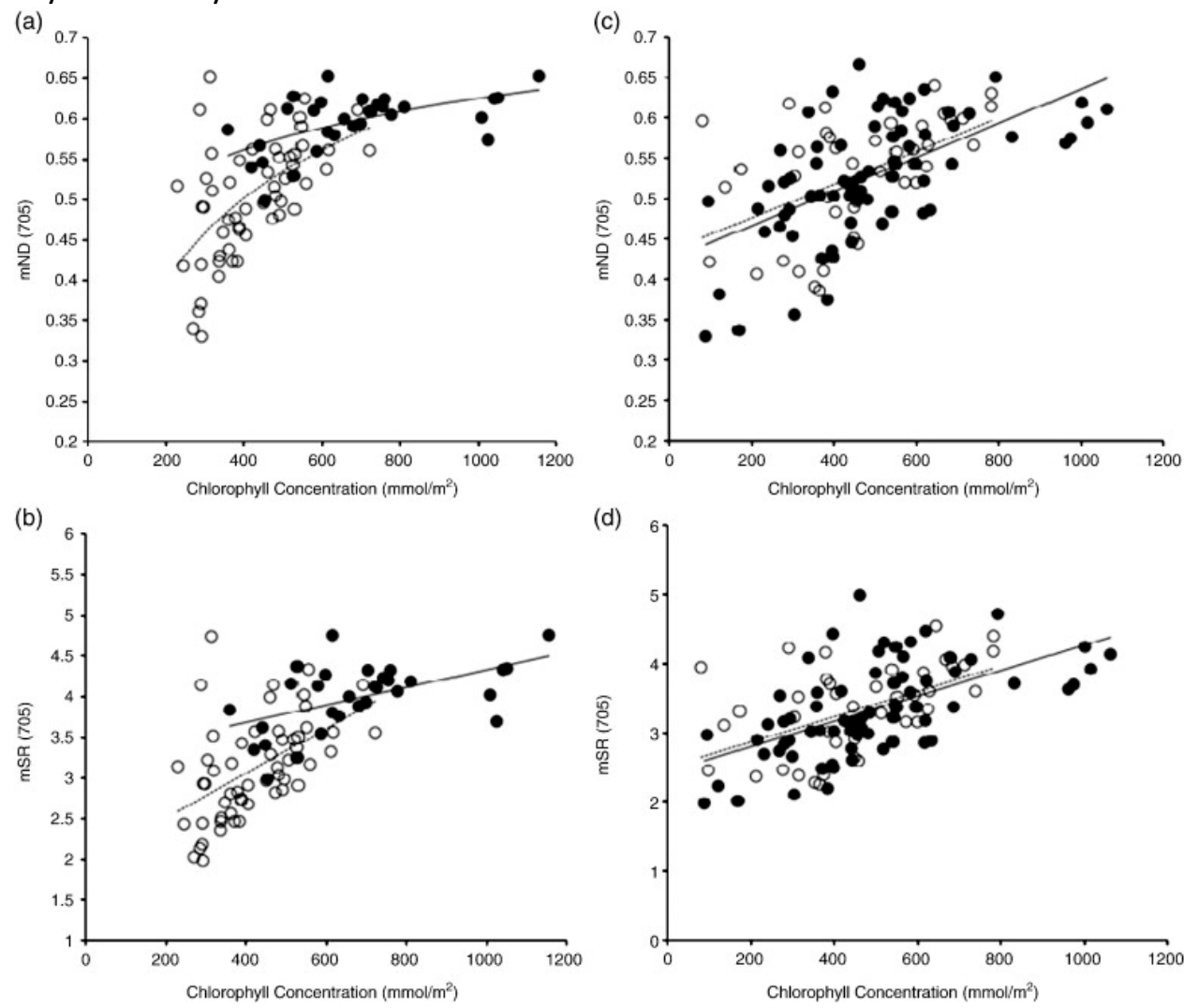

Fig. 3. Correlations between hyperspectral vegetation indexes and chlorophyll concentration for (a-b) tropical

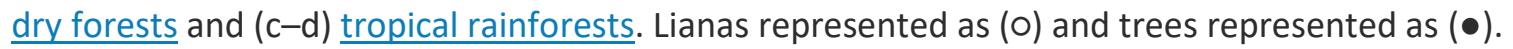



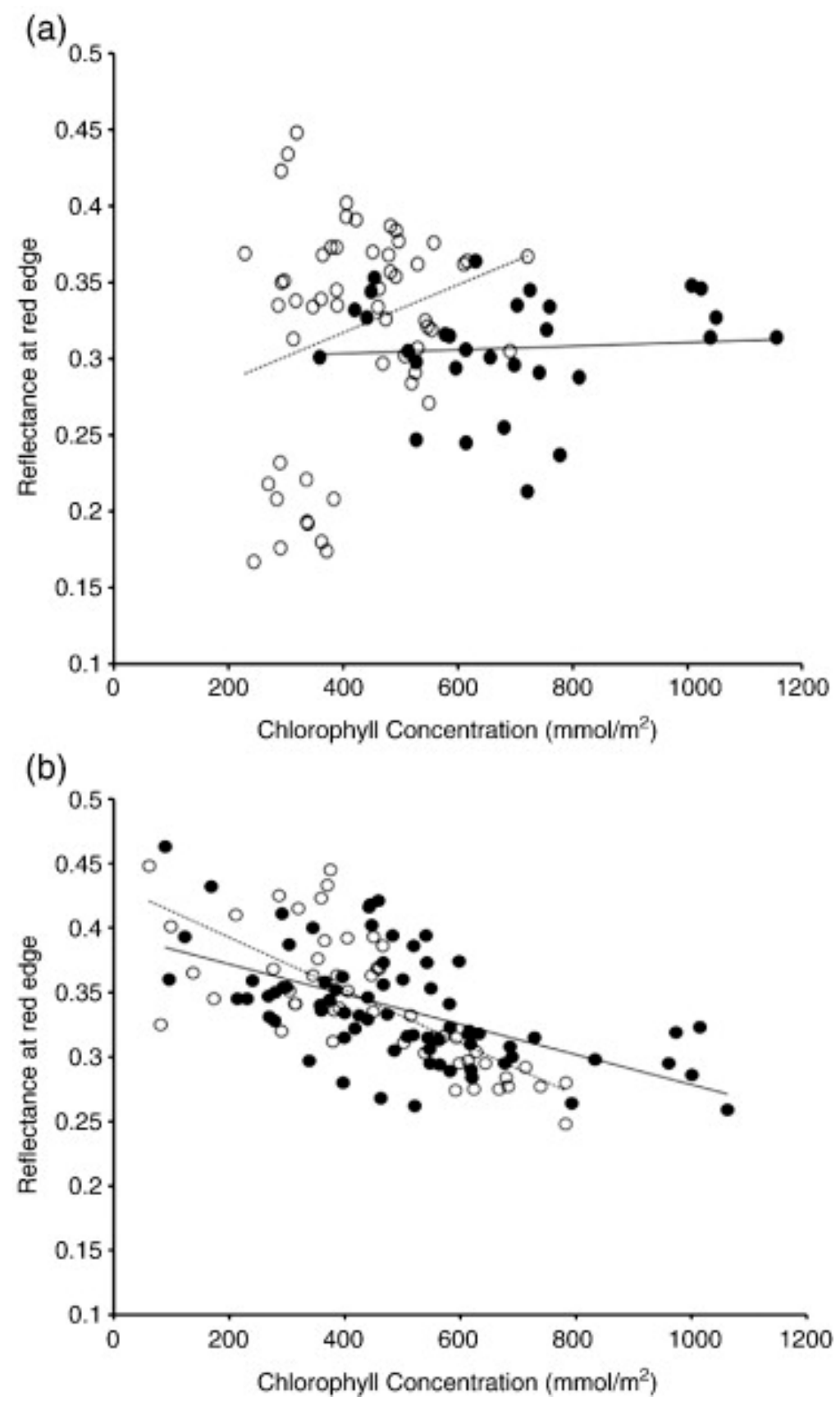

Fig. 4. Correlation between the position of the red-edge and chlorophyllconcentration for (a) tropical dry forest and (b) tropical rainforest site. Lianas represented as (0) and trees represented as $(\bullet)$.

The Bhattacharrya test statistic $(B)$ indicates a greater degree of separability between the liana and tree reflectance spectra at the dry forest site ( $\underline{\text { Fig. }}$ a) in comparison to the rainforest site (Fig. $5 \mathrm{~b}$ ) in the 400$1100 \mathrm{~nm}$ range. The dominant peaks in separability occur near $500 \mathrm{~nm}, 675 \mathrm{~nm}$ and $720 \mathrm{~nm}$ for the dry forest and $720 \mathrm{~nm}$ for the rainforest (although at a much lower magnitude). This range $(500-720 \mathrm{~nm}$ ) represents the chlorophyll/carotenoid absorption region. 
(a)

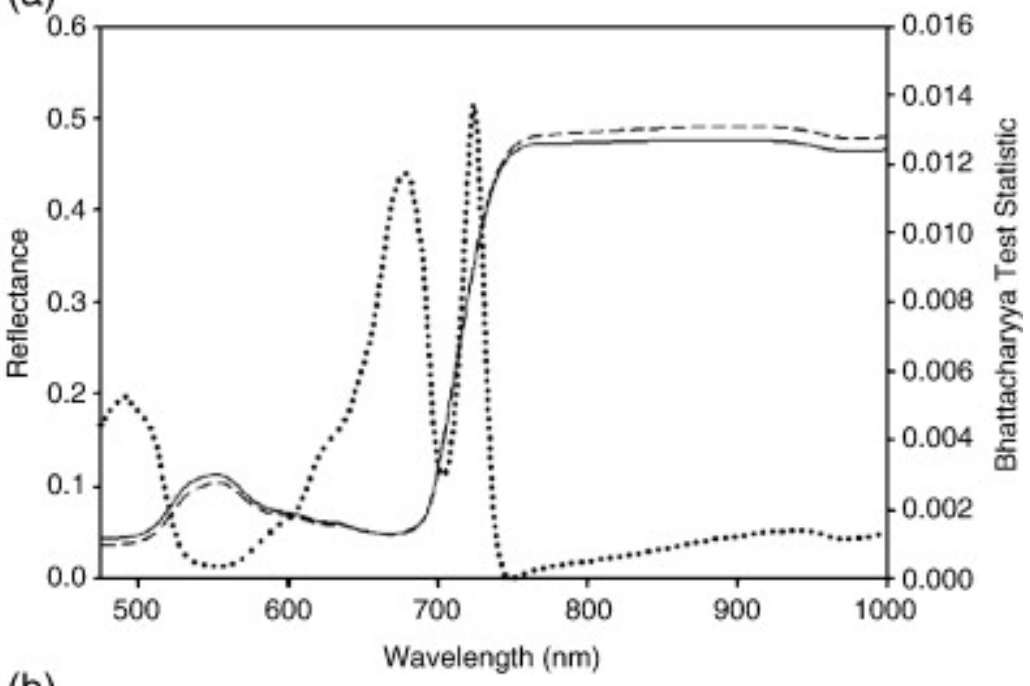

(b)

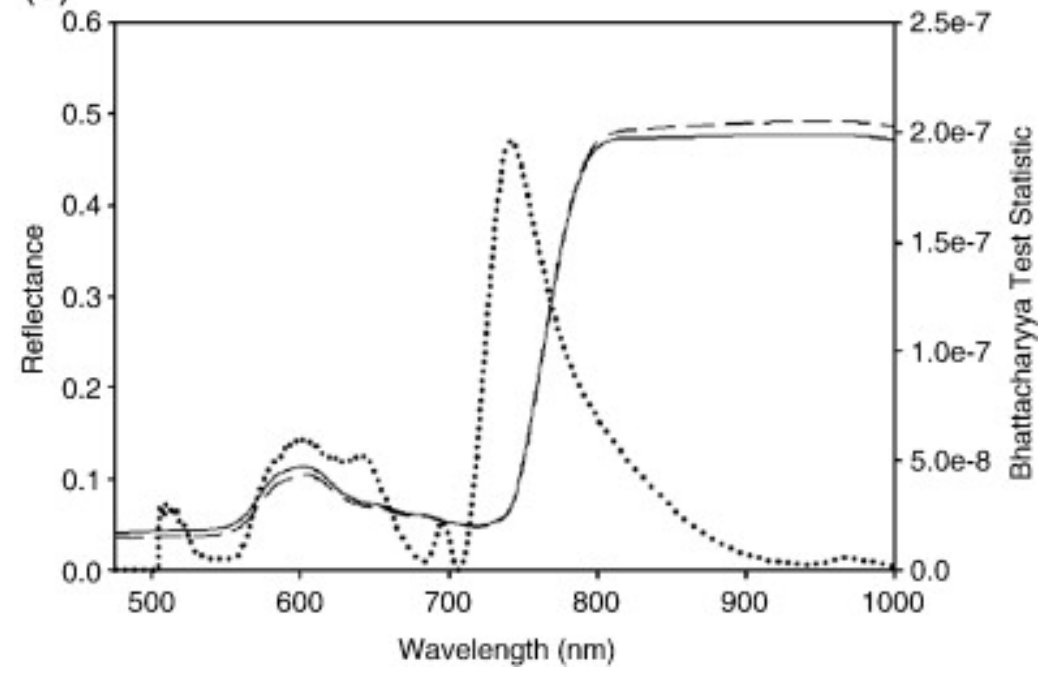

Fig. 5. Spectral correlation and most significant bands based on the Bhattacharyya test statistic for (a) Parque Natural Metropolitano Dry forest and (b) Fort Sherman rainforest crane sites. More significant spectral bands are observed by peaks on the Bhattacharyya index. The Bhattacharrya test statistic indicates a greater degree of separability between the liana and tree spectra at the dry forest site (peaks in the range of 0.0050.014 ) in comparison to the rainforest site (peaks in the range of $5.0 \times 10^{-8}-2.0 \times 10^{-7}$ ) in the 400-1100 nm range. The dominant peaks in separability occur near $500 \mathrm{~nm}, 675 \mathrm{~nm}$ and $720 \mathrm{~nm}$ for the dry forest and $720 \mathrm{~nm}$ for the rainforest (although at a much lower magnitude). For the dry forests the most significant bands are 500, 675 and $720 \mathrm{~nm}$. For the rainforest the only slight difference is observed at $720 \mathrm{~nm}$.

In addition to the differences observed in pigment concentration and spectral reflectance at given wavelengths and spectral indices, lianas had significantly lower total absorptance than their host trees across the entire spectrum at the dry forest (Fig. 6a) $(t=-33.708, p<0.0001)$. This difference is sharpest at $550 \mathrm{~nm}$. Lianas also tend to have higher transmittance than trees in both the visible and near infrared range $(t=36.196, p<0.0001)$. These sharp differences are far less distinct for the liana and tree species co-existing at the rainforest site. A slight difference between lianas and trees is observed at $550 \mathrm{~nm}$ for the rainforest site but this difference is not statistically significant (Fig. 6b). Our results on the absorptance properties of lianas and trees contrast with those of Avalos et al. (1999) for the same dry forest site (rainforest crane was not sampled) and season. Avalos et al. (1999), using a reduce number of species of trees (7) and lianas (12) found no significant differences between 
absorptance, transmittance and reflectance between trees and lianas. We attribute these differences to the reduce number of species sampled by Avalos et al. (1999) in contrast with this study.
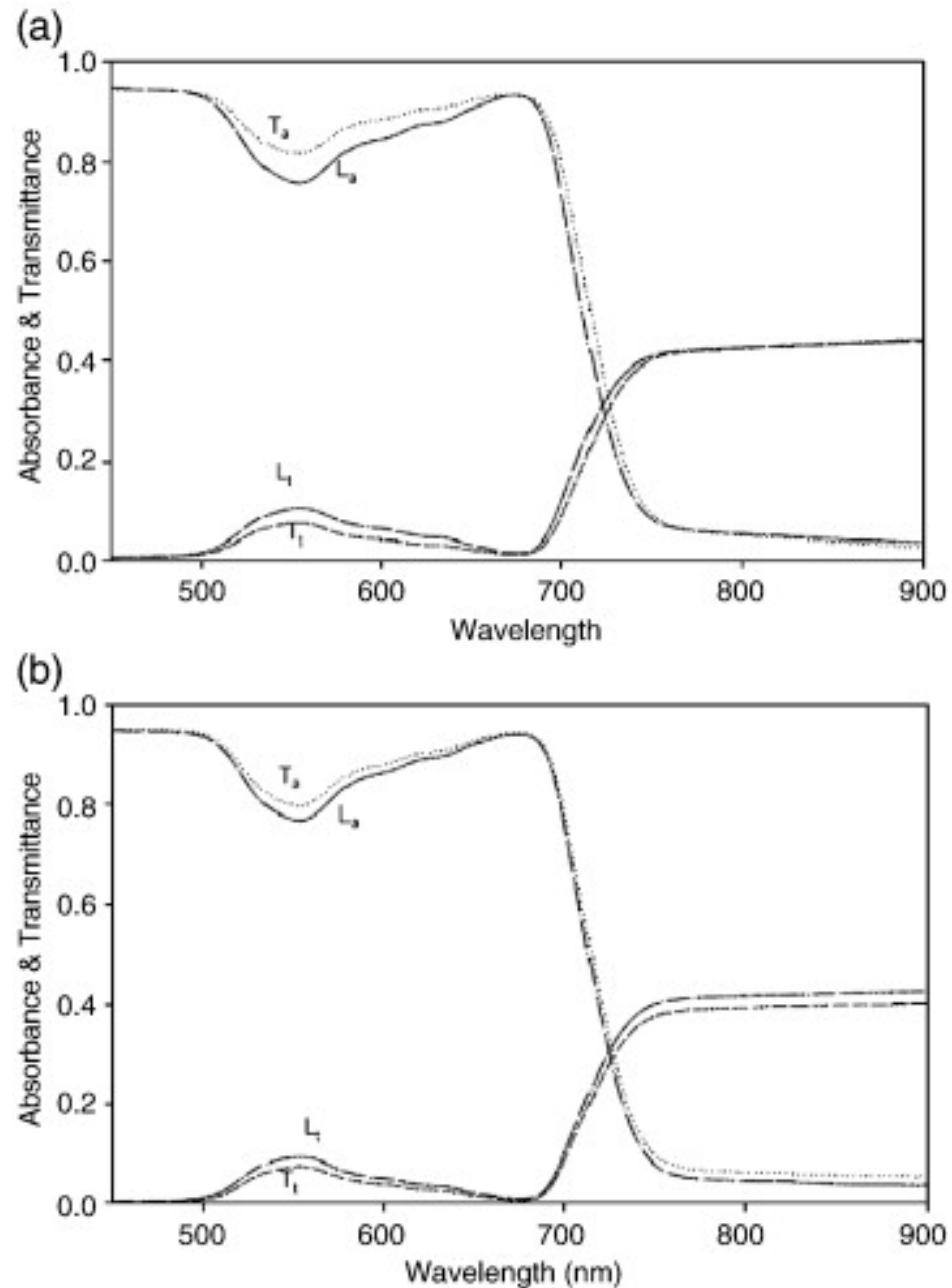

Fig. 6. Absorptance and transmittance for lianas and trees from (a) Parque Natural Metropolitano dry forest and (b) Fort Sherman rainforest crane sites. Lianas, in both sites, have higher light transmittance than trees in the visible range. Their absorptance and transmittance patterns are not statistically significantly different in the infrared. Lines represent the mean values for each life form. Ta: Tree absorbance, Tt: Tree transmittance, La: Liana absorptance and Lt: Liana transmittance.

\subsection{Do leaf internal structure and near-infrared reflectance differ between life forms?}

Our results indicate that the relationship between reflectance at $800 \mathrm{~nm}$ and empty spaces in the mesophyll layer is scattered and lacks a clear separation between lianas and trees based on internal leaf structure (Fig. 7). Overall, Lianas average $50 \%$ more intercellular air space in the mesophyll than do trees although the difference is not significant given the large degree of variability observed between the different life forms and samples from both sites (dry forest: $t=1.353, p=0.816$; rainforest: $t=-0.298, p=0.769$ ). Further, there was no significant life form - location effect on the amount of intercellular air space $(p=0.236)$. 


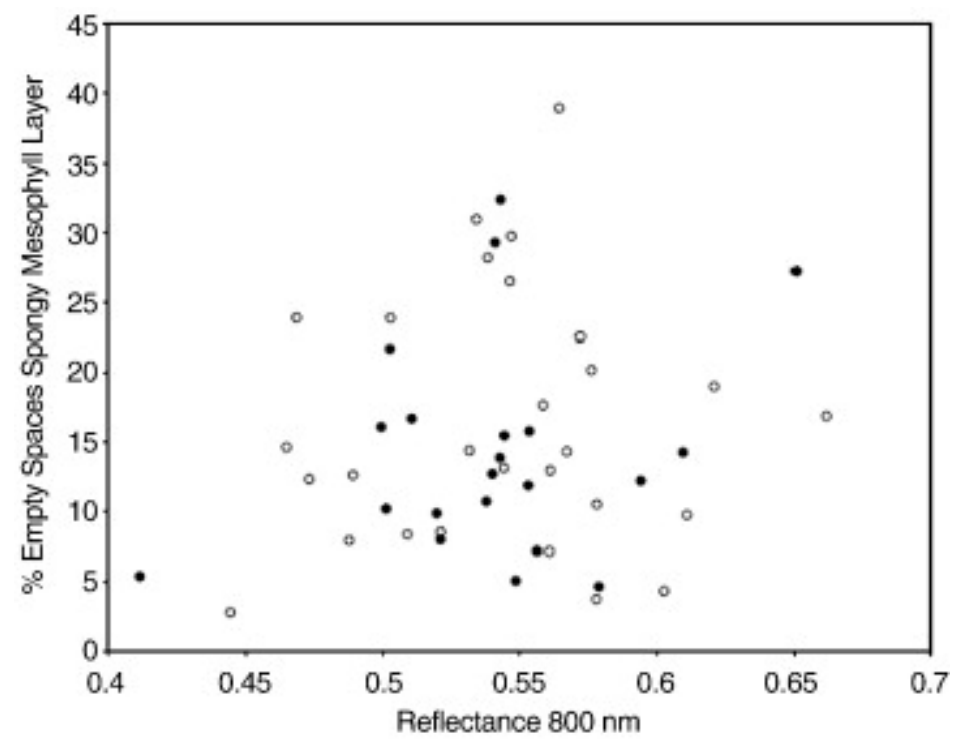

Fig. 7. Relationship between spectral reflectance at $800 \mathrm{~nm}$ and the percentage of empty spaces on the spongy mesophyll layer of selected liana $(0)$ and tree $(\bullet)$ species.

The large variability observed in leaf internal structure (empty spaces in the mesophyll layer (see Fig. 8 for samples of such variability) is also reflected in the reflectance at $800 \mathrm{~nm}$ where there is no significant difference between lianas and trees at either site (dry forest: $t=1.325, p=0.189$ and rainforest: $t=-0.012, p=0.999$ ). This lack of separability is also seen for both forest sites using the Bhattacharyya test statistic for the near infrared

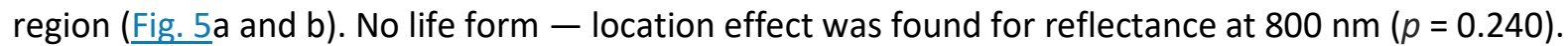


(a)

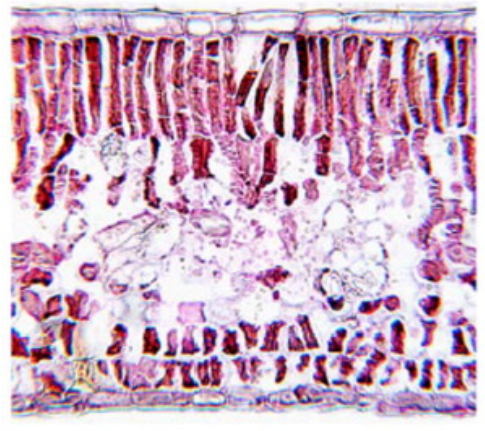

(b)

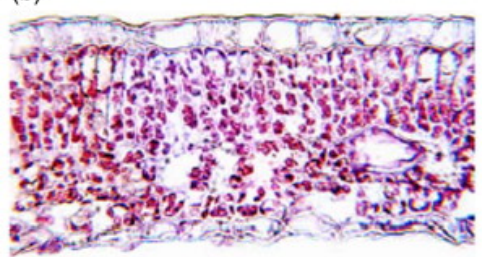

(c)

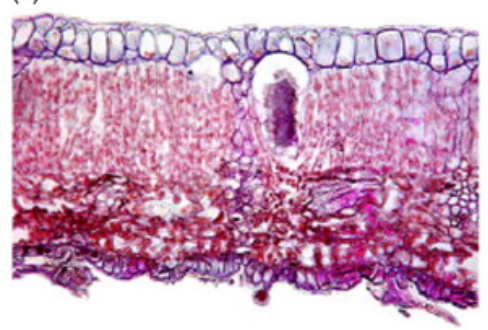

(d)

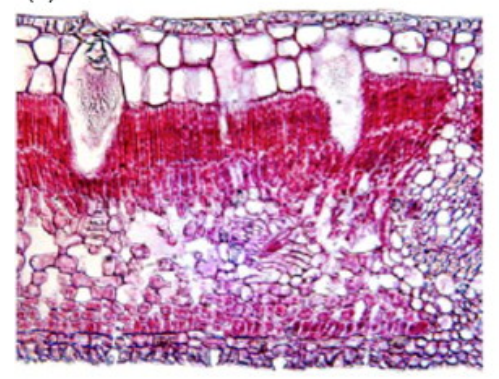

(e)

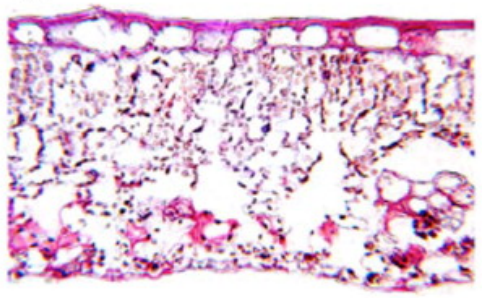

(f)

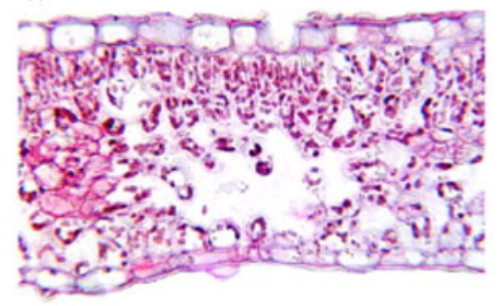

(g)

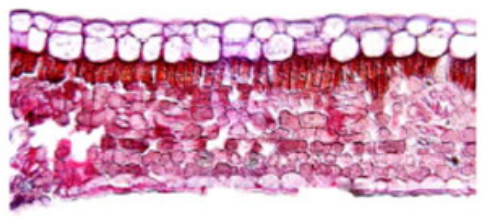

(h)

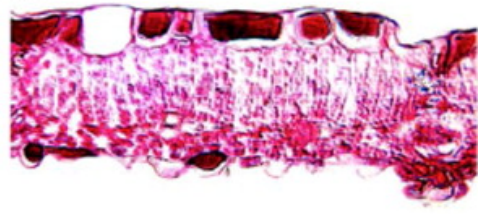

(i)

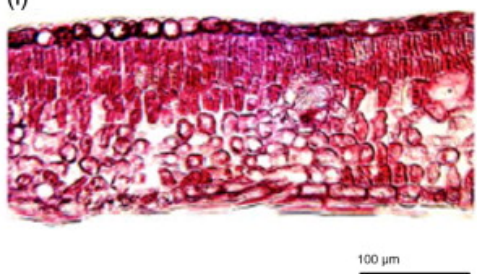

Fig. 8. Selected cross section of leaves from trees and lianas at the Parque Natural Metropolitano dry forest crane site. Information in parentheses represents the average percentage of empty spaces, average leaf thickness and average percentage spectral reflectance at $800 \mathrm{~nm}$, respectively. Trees: (a) Anacardium excelsum (12.2\%, $0.268 \mathrm{~mm}, 58.4 \%)$, (b) Annona spraguei (9.9\%, $0.259 \mathrm{~mm}, 51.9 \%)$, (c) Cordia alliodora (15.4\%, $0.290 \mathrm{~mm}, 54.4 \%)$, (d) Ficus insipida (29.3\%, $0.378 \mathrm{~mm}, 54.1 \%)$. Lianas: (e) Mikania leiostachya (38.9\%, $0.384 \mathrm{~mm} .56 .5 \%)$, (f) Aristolochia maxima (23.9\%, $0.346 \mathrm{~mm}, 50.3 \%)$, (g) Doliocarpus major (17.66\%, $0.209 \mathrm{~mm}$, $55.8 \%)$, (h) Passiflora vitifolia (8.3\%, $0.179 \mathrm{~mm}, 50.9 \%)$, and (i) Bonamia trichantha $(9.74 \%, 0.226 \mathrm{~mm}$, $61.11 \mathrm{~mm}$ ). Scale bar represents $100 \mu \mathrm{m}$.

\subsection{Do leaf trait properties such as Specific Leaf Area (SLA), leaf thickness, water} content, and nitrogen $(N)$ and phosphorus $(P)$ concentration differ between life forms? SLA ( $\mathrm{m}^{2} / \mathrm{kg}$ ) was significantly higher for lianas than for trees at both crane sites (Table 2, Fig. 9) (dry forest: $t=4.804, p<0.0001$ and rainforest: $t=4.545, p<0.0001$ ). A highly significant life form - location interaction was also found $(p<0.001)$. Moreover, liana leaves were significantly thinner than leaves of their host trees at both crane sites (dry forest: $t=-7.025, p<0.0001$ and rainforest: $t=-2.624, p=0.0045$ ) (Table 2). However, for leaf thickness, no significant life form - location interaction was found $(p=0.274)$. 


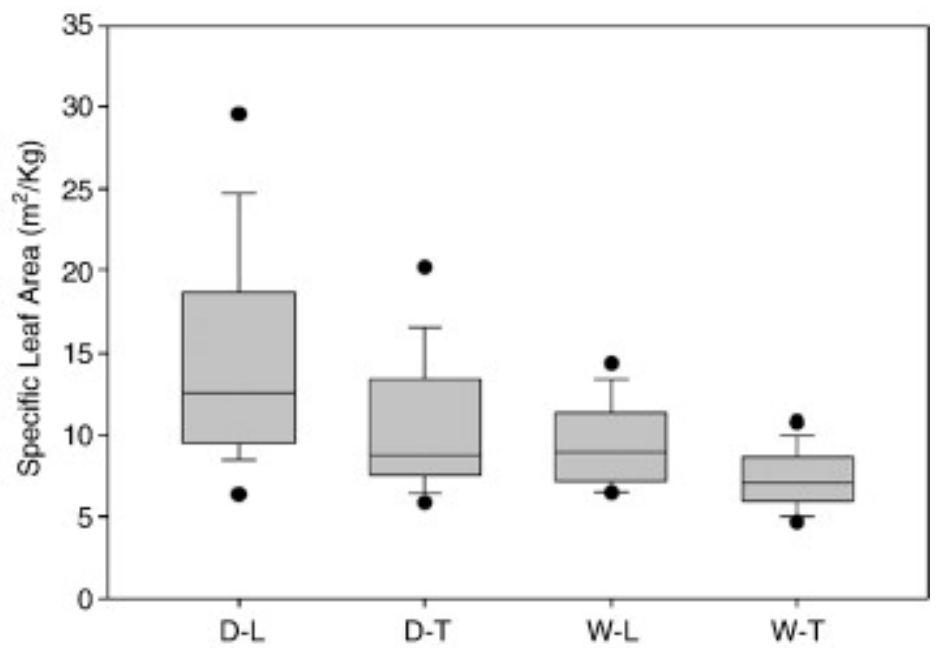

Fig. 9. Box plots for Specific Leaf Area for lianas (L) and trees (T) in a tropical dry (D) and rainforest (W). Differences are more pronounced among life forms in the tropical dry forests. The box plots are explained in the caption of Fig. 1.

Liana leaves tended to have higher water content than tree leaves in both sites. Leaf water content was $16.1 \%$ (64.6\% vs. $55.6 \%$ ) and $11.1 \%$ (61.6 vs. $54.7 \%$ ) higher in lianas than in trees at both crane sites, respectively. The difference in water content was also statistically significant among life forms for data collected at both crane sites. No significant life form - location interaction was found for water content $(p=0.772)$.

Although differences are observed in total water content at the leaf level for both structural groups, our three water spectral analysis: Water Band Index (WBI ${ }_{970}$ ), Gausian continuum removal (conducted over 900-1000 nm region on a Gaussian smoothed data set with a 7 bands window size), and the continuous wavelet analysis did not shown any statistical significant differences among structural groups or sites (Table 2). Because $970 \mathrm{~nm}$ is a weak water absorption feature near the edge of UNISPEC(C) detector sensitivity, where noise and second-order effects can cause serious artifacts (Fig. 10), technical limitations prevent for conclusive results. In both analyses, continuum removal using the Gaussian model and the wavelet analysis the water feature was centered at $965 \mathrm{~nm}$ for most species. 


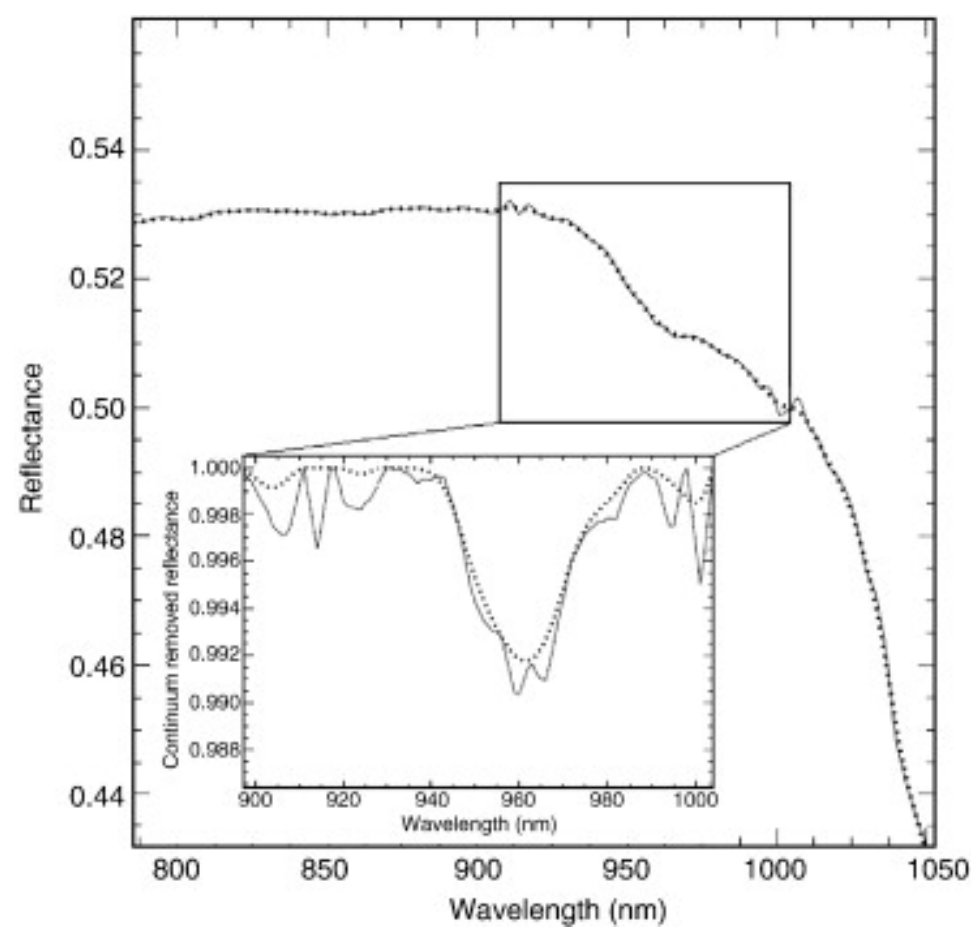

Fig. 10. Gaussian filtering (smoothing) of a liana spectrum around the $965 \mathrm{~nm}$ water band absorption region. Solid line $=$ original UNISEPC spectrum, dashed line $=$ smoothed spectrum. Notice the second order effects after $1000 \mathrm{~nm}$.

Statistically significant differences between lianas and trees were observed for the leaf dry matter content (dry:fresh mass ratio) at the dry forest sites (Table $2, t=-6.836, p<0.001$ ). However, a significant life form location interaction was found for dry matter content $(p=0.001)$.

Leaf $\mathrm{N}$ and $\mathrm{P}$ concentrations were statistically indistinguishable for lianas and trees at both sites (Table 2). No significant life form - location interaction was found for either $\mathrm{N}(p=0.805)$ or $\mathrm{P}(p=0.658)$. At the PNM ( $\underline{\text { Fig. }}$. 11), SLA and leaf $N$ and $P$ concentrations tended to cluster between $5-18 \mathrm{~m}^{2} / \mathrm{kg}, 2-3 \%$ and $0.1-0.2 \%$ for trees, respectively, while lianas covered a wider range of values. No clustering or differences among trees and lianas were observed at the rainforest site. In general, nutrient levels were higher in leaves of both life forms at the dry forest site (PNM) than at the rainforest site (FS) (Table 2). 
(a)

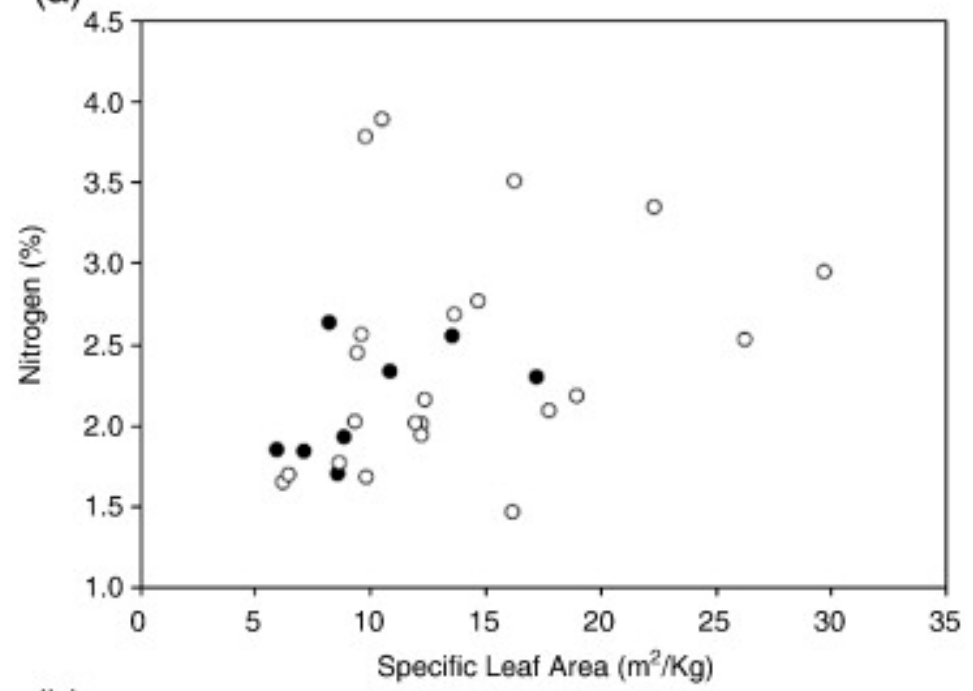

(b)

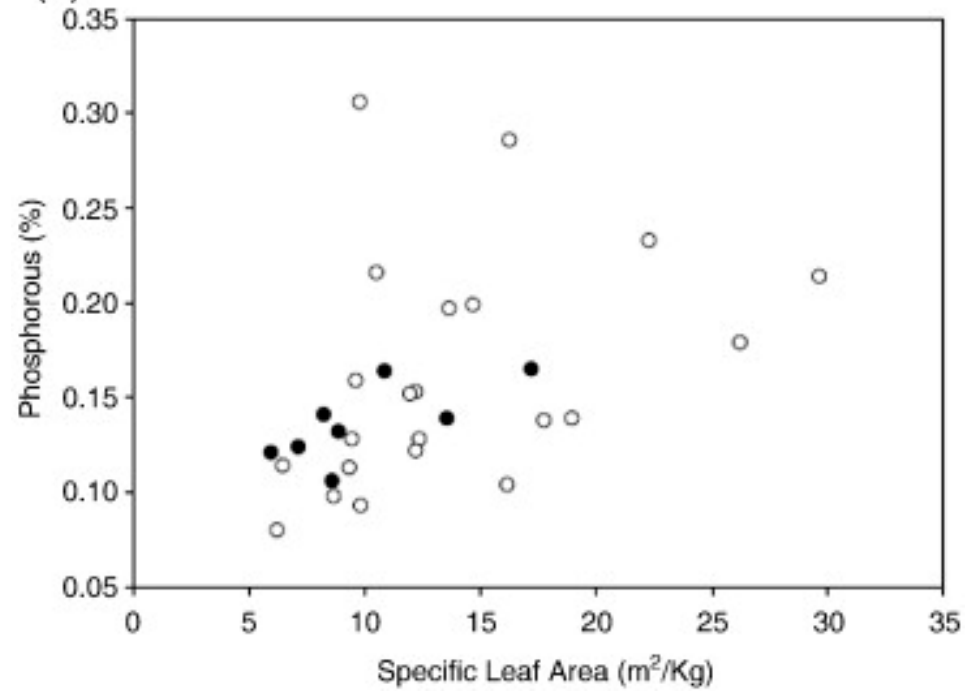

Fig. 11. Relationships between nitrogen and phosphorus (\%), (a) specific leaf area $\left(\mathrm{m}^{2} / \mathrm{Kg}\right.$ ) and nitrogen (\%), and (b) specific leaf area $\left(\mathrm{m}^{2} / \mathrm{Kg}\right)$ and phosphorus (\%), for the tropical dry forest site showing separability between structural groups. Lianas represented as (०) and trees represented as $(\bullet)$.

\section{Discussion}

\subsection{Differences in leaf trait between life forms}

Our data indicate that there are significant differences in pigment levels, structural traits, and optical properties for leaves of lianas and trees in a tropical dry forest, but not in a tropical rainforest (Table 2). At both of our sampling sites, liana leaves are thinner and have higher water content than tree leaves. At the tropical dry forest, liana leaves also have lower chlorophyll and carotenoid concentrations, lower leaf dry matter content and higher total area to dry mass (SLA) than tree leaves. Additional trends observed at the tropical dry forest site (although not statistically significant) include a larger proportion of intercellular space in the spongy mesophyll layer and higher nitrogen and phosphorus concentrations (\%) for liana leaves as compared to tree leaves. Limited differences between the two life forms at the tropical rainforest site were consistent with Castro-Esau et al. (2004), whose work - using machine learning classifiers - showed that reflectance spectra of lianas and trees were not clearly separable in the $400-1100 \mathrm{~nm}$ range. These results tend to be similar to observations at a 
Mexican and Brazilian tropical dry and rainforest sites (M. Quesada and M. de Espirito Santo, personal communications), suggesting the presence of a general pattern across latitude.

The observed differences in pigment concentration (chlorophyll and carotenoid) were reflected in the two spectral indices used in this study, as well as in the red edge analysis. No significant differences were observed between life forms for reflectance at $800 \mathrm{~nm}$, which is affected by the number of air to cell wall interfaces in the spongy mesophyll layer. This lack of difference for reflectance at $800 \mathrm{~nm}$ is related to the large variability in percentage empty space observed within life forms (Fig. 7, Fig. 8). This large natural variability prevents a broader generalization that could indicate whether liana leaves reflect more light in the near infrared than tree leaves because no statistically significant differences are observed between these two life forms. Future analysis using the ratio of mesophyll cell surface area exposed to intercellular spaces per unit leaf surface area, as described in Slaton et al. (2001), may provide a better indication of leaf near infrared reflectance for the two life forms, as this ratio more closely describes air to cell wall interfaces than does percentage air space (Knipling, 1970, Castro-Esau et al., 2006).

Finally, the differences in water content between lianas and trees in both crane sites do not show up in the $970 \mathrm{~nm}$ water index nor on the two different continuum removal analyses. As mentioned above, we attribute this lack of separability to technical limitations of our instrument. Further research using a full range spectrometer (including additional water absorption bands in the shortwave infrared region) can provide important insights on the effects of water content on spectral reflectance, and provide new avenues for research associated with the use of water bands as a tool to potentially identify liana communities.

\subsection{Causes of differences across environments}

Different levels of water stress in the two forests might contribute to the differences observed between lianas and trees. The dry forest site has a severe five-month dry season when low cloud cover and high solar irradiance enhances the potential for leaf-level water stress. In contrast, the rainforest site receives $1560 \mathrm{~mm}$ more rainfall each year, and has a shorter, milder, cloudier dry season and far less potential for water stress to develop. Schnitzer (2005) suggested that lianas, because of their more efficient vascular system, are exposed to the potential for more water stress and drought-induced embolism in tropical dry forests than in tropical rainforests, which could also have contributed to the significant differences in water content, chlorophyll and carotenoid concentrations as coping mechanisms.

Schnitzer (2005) and Andrade et al. (2005) have suggested that lianas cope with dry season drought by having deep roots and efficient vascular systems, which allow lianas to bring more water to the canopy and to maintain higher leaf water content than do trees. Higher leaf water content might explain why lianas tend to be evergreen (Putz \& Windsor, 1987) or to lose their leaves later in the dry season than do trees (Kalascka et al., 2005). Higher spectral reflectance, higher transmittance, and lower absorptance will also reduce heat load, leafto-air vapor pressure differences, and the potential for water stress. These specific adaptations are typical of the lianas growing at the dry forest site. Furthermore, although differences were not significant, our results are consistent with previous observations by Wright and Westoby (1999), who suggested that higher $\mathrm{N}$ concentrations among arid zone species are associated with higher water conservation.

\subsection{Liana leaf traits in the context of competitive adaptation mechanisms}

Lianas in tropical dry forests appear to have a competitive advantage over trees by maintaining the ability to grow during the dry season. In fact, many lianas species tend to remain photosynthetically active during the dry season while many trees are dormant, allowing lianas to grow and expand their dominance of the canopy (Zotz and Winter, 1996, Schnitzer and Bongers, 2002, Schnitzer, 2005). To accomplish dry season growth, lianas must be more efficient in terms of resource allocation at the leaf level. Specific liana leaf traits - including higher SLA, 
higher (but not statistically significant) nitrogen, and phosphorus concentration and lower ratio of dry mass to fresh mass compared to trees - all support the idea that lianas have more efficient resource allocation to maximize dry season growth (Table 2). In turn, these leaf-level attributes may explain the high relative abundance of lianas in tropical dry forests (Schnitzer, 2005).

The integration of SLA, nitrogen, phosphorus and leaf dry matter content provides important information regarding how liana and tree leaves survive in the top of the canopy. Pooter and De Jong (1999) have indicated that SLA is not only a key variable explaining traits associated with relative growth rate (RGR), but it is also an important variable to explain tradeoffs between resource capture and conservation. Our data support Pooter and De Jong's (1999) capture/conservation theory. The different liana traits (lower chlorophyll concentration, thinner leaves, higher SLA, slightly higher nitrogen and phosphorus concentration and lower leaf dry matter content) indicate that lianas tend to have a higher rate of resource acquisition in contrast with trees that tend to focus more on the conservation of acquired resources (lower SLA, Lower N and P and higher leaf dry matter content).

The relationships observed between liana and tree SLA, and their $\mathrm{N}$ and $\mathrm{P}$ concentration in the tropical dry forest site (Fig. 11), a relationship that has also been documented by others but not in the context of separating lianas and trees (Pooter and De Jong, 1999, Wright et al., 2001, among others), may provide important insights on how SLA can be eventually used as a tool to separate these two life forms. Of particular interest is the statistically significant difference for SLA among life forms at the tropical dry forest site but not at the tropical rainforest site (Fig. 9).Wright et al. (2001) has suggested that higher SLA is associated with less structural material relative to metabolic components, less internal shading and shorter gas diffusion paths, larger intercellular air spaces, and consequently greater carbon assimilation. These elements can in turn be related to water loss strategies, with the higher SLA lianas more prone to water loss via evapotranspiration. This may be related to the reduced need for structural support, allowing lianas to invest more in water acquisition and transport, which can help explain liana's higher water content and larger intercellular air spaces. Thus, it appears that, from an ecophysiological perspective, lianas are functionally distinct from trees, and this difference is especially clear in dry sites, where adaptations related to water acquisition and gas exchange are revealed in a number of physiological, structural, and optical features observed in this study.

\subsection{Links to remote detection}

Our results using two narrow band hyperspectral vegetations indices - applied here at the leaf level - suggest that for our selected sites the remote detection of liana communities using air or spaceborne sensors may be possible for the in tropical dry forests site but not for rainforest. Our results at the leaf level helps to explain the findings by Sánchez-Azofeifa and Castro-Esau (2006) and Kalácska et al. (2007) who demonstrated, using machine learning algorithms that scaling from leaf-level to canopy level, and then from leaf-level to landscape level can be achieved with some degree of success in a tropical dry forest only. Nonetheless, further research is required to carefully and accurately scale-up from leaf observations to canopy and landscape levels across different tropical life zones.

The lack of differences in the two chlorophyll indices and the water index used in this study, in combination with our findings of no significant differences in other leaf traits for tropical rainforests, indicates that it is unlikely that remote sensing methods that use the wavelength region examined in this paper $(400-1100 \mathrm{~nm})$ will be able to distinguish lianas from trees in this forest type. Lianas in tropical rainforest environments do not flush their leaves in synchrony, as do dry forest lianas. Rather, they live in a constant and extremely dynamic state of transition among young to mature leaves, a state that complicates their potential separability at the canopy and landscape level. Shortwave infrared (up to $2500 \mathrm{~nm}$ ) could lead to a positive identification of liana communities present in rainforest environments, but this remains untested. 
Success on scaling-up from leaf to canopy to landscape levels using remote sensing observations is compounded by many factors. One likely factor is the high degree of spectral mixing resulting from having multiple liana species present in one single tree at one given time (Castro-Esau et al., 2004, Sánchez-Azofeifa and Castro-Esau, 2006), as well as liana interactions with the spectral properties of their host trees (Kalácska et al., 2007, Zhang et al., 2006). Exceptions to our observations could be very simplistic scenarios (e.g., monodominant forests, see Foster et al., 2008) in which lianas are present in high numbers but with one single species (e.g., Graul \& Putz, 2004), similar to those observed in Bolivia.

Further factors not considered in this study, but that must be considered from a remote sensing prospective, include the effects of multiple scattering in liana infested and non-infested canopies, tree canopy architecture, and liana species composition and their density at the crown level. In addition, success in positively identifying the presence of lianas at a local or regional level (as part of a long term monitoring program) will require a clear understanding of liana/tree intra and inter-specific spectral variability as well climatic and phenological conditions.

Finally, our field observations, although limited to a specific region in Panama, provide important baseline information for further refining multiple scattering modeling efforts that have not yet considered the presence of lianas on the canopy. We believe that further analyses and modeling must be done before we are able to make broad generalizations regarding the possibility of detecting the presence, absence, or change in liana density at the landscape level for both tropical dry and rainforest environments.

\section{Conclusion}

On the surface, our findings that lianas and trees leaves are spectrally distinct and have significantly different leaf traits and pigment concentrations in dry forests but not rainforests appears to present a paradox. We hypothesize that lianas and trees exhibit contrasting degrees of plasticity in their leaf traits in response to environmental conditions, and that water and light levels may be the main drivers for these differences between sites. Differences in leaf responses associated with contrasting environments may also be explained by contrasting resource allocation strategies; because lianas do not need to invest as much in structural support as trees (Schnitzer, 2005), they may be able to invest more resources in water transport and photo-protection when faced with drought and high light. Further work would be needed to explore this hypothesis, and transplant or common garden experiments may be one way to test this. Common garden experiments would also enable us to better understand the extent to which these features represent plastic physiological adjustments vs. fixed genetic traits. A greater understanding of the genetic and physiological differences underlying this pattern might help identify hyperspectral remote sensing approaches to better distinguish lianas and trees in tropical dry forests environments in the future.

Taken together, the findings presented in this study suggest the possibility of a "liana syndrome" - $a$ distinct set of liana traits or adaptations that are clearly revealed in tropical dry forests but not rainforests. This contrasting expression in these two different forest types brings us to hypothesize that this syndrome is driven by environmental conditions (water stress and light availability), and are related to the liana's reduced need for structural support and consequently greater effectiveness in capturing water and nutrients than host trees (Schnitzer, 2005). This syndrome may partly explain the apparent expansion of lianas in tropical forests in recent years (Phillips et al., 2002, Phillips et al., 2005, Wright et al., 2004), and suggests further changes in forest composition linked to changing rainfall patterns may continue to occur in tropical environments, with potentially large impacts on forest structure, composition, and biodiversity. A full understanding of this syndrome could be useful in developing a basis for distinguishing lianas and trees using hyperspectral remote sensing platforms in tropical dry forest environments, and may help us understand how tropical ecosystems will continue to respond to climate change. 


\section{Acknowledgements}

We thank the help of Mirna Samarniego who provided important insights on species identification at both tropical canopy cranes in Panama. The Smithsonian Tropical Research Institute, the Natural Sciences and Engineering Research Council of Canada (Discovery grant program), and the Inter American Institute for Global Change Research Collaborative Research Network (CRN2-021) program that is supported by the U.S. National Science Foundation (Grant GEO-0452325) supported this work. We also want to thank the suggestions and comments from three anonymous reviewers.

\section{References}

Alvira D., Putz F.E., Fredericksen T.S. Liana loads and post-logging liana densities after liana cutting in a lowland forest in Bolivia Forest Ecology and Management, 190 (1) (2004), pp. 73-86

Andrade J.L., Meinzer R., Goldstein G., Schnitzer S.A. Water uptake and transport in lianas of a seasonal dry tropical forest Trees: Structure and Function, 19 (3) (2005), pp. 282-289

Avalos G., Mulkey S.S., Kitajima K. Leaf optical properties of trees and lianas in the outer canopy of a tropical dry forest Biotropica, 31 (3) (1999), pp. 517-520

Bhattacharyya A. On a measure of divergence between two statistical populations defined by probability distributions Bulletin of the Calcutta Mathematical Society, 35 (1943), pp. 99-109

Bruce L.M., Li J. Wavelets for computationally efficient hyperspectral derivative analysis IEEE Transactions on Geoscience and Remote Sensing, 39 (7) (2001), pp. 1540-1546

Bruce L.M., Mathur A., Byrd J.D. Denoising and wavelet-based feature extraction of MODIS multi-temporal vegetation signatures GIScience and Remote Sensing, 43 (2006), pp. 170-180

Castro-Esau K.L., Sánchez-Azofeifa G.A., Caelli T. Discrimination of lianas and trees with leaf-level hyperspectral data Remote Sensing of Environment, 90 (3) (2004), pp. 353-372

Castro-Esau K.L., Sánchez-Azofeifa G.A., Rivard B., Wright S.J., Quesada M. Inter and intra species variability of spectral reflectance of tropical trees American Journal of Botany, 93 (4) (2006), pp. 517-530

Clark M.L., Roberts D.A., Clark D.B. Hyperspectral discrimination of tropical rainforest tree species at leaf to crown scales Remote Sensing of Environment, 96 (2005), pp. 375-398

Clark R.N., Roush T.L. Reflectance spectroscopy, quantitative analysis techniques for remote sensing applications Journal of Geophysical Research, 89 (No B7) (1984), pp. 6329-6340

Cochrane M.A. Using vegetation reflectance variability for species level classification of hyperspectral data International Journal of Remote Sensing, 21 (10) (2000), pp. 2075-2087

Foley S., Rivard B., Sánchez-Azofeifa G.A. Foliar spectral properties following leaf clipping and implications for handling techniques Remote Sensing of Environment, 103 (3) (2006), pp. 265-275

Foster J.R., Townsend P.A., Zganjar C.E. Spatial and temporal patterns of gap dominance by low-canopy lianas detected using EO-1 hyperion and landsat thematic mapper Remote Sensing of Environment, 112 (5) (2008), pp. 2104-2117

Gamon J.A., Serrano L., Surfus J.S. The photochemical reflectance index: an optical indicator of photosynthetic radiation use efficiency across species, functional types, and nutrient levels Oecologia, 112 (1997), pp. 492-501

Gamon J.A., Kitajima K., Mulkey S.S., Serrano L., Wright S.J. Diverse optical and photosynthetic properties in a neotropical forest during the dry season, implications for remote estimation of photosynthesis Biotropica, 37 (4) (2005), pp. 547-560

Gausman H.W., Allen W.A., Cardenas R. Reflectance of cotton leaves and their structure Remote Sensing of Environment, 1 (1969), pp. 19-22

Gentry A.H. The distribution and evolution of climbing plants F.E. Putz, H.A. Mooney (Eds.), The biology of vines, Cambridge University Press (1991)

Graul W.T., Putz F.E. Effects of lianas on growth and regeneration of Prioria copaifera in Darien, Panama Forest Ecology and Management, 190 (2004), pp. 99-108 
Kalascka M., Calvo J., Sánchez-Azofeifa G.A. Assessment of seasonal changes in species' leaf area in a tropical dry forest in different states of succession Tree Physiology, 25 (2005), pp. 733-744

Kalácska M., BohIman S., Sánchez-Azofeifa G.A., Castro-Esau K.L., Caelli T. Hyperspectral discrimination of tropical dry forest lianas and trees: comparative data reduction approaches at the leaf and canopy levels Remote Sensing of Environment, 109 (4) (2007), pp. 406-415

Knipling E.B. Physical and physiological basis for the reflectance of visible and near-infrared radiation from vegetation Remote Sensing of Environment, 1 (1970), pp. 155-159

Landgrebe D. Signal Theory Methods in Multispectral Remote Sensing Wiley (2003)

Laurence W.F., Perez-Salicrup D., Delamonica P., Fearnside P.M., D'Angelo S., Jerozolinski A., et al. Rainforest fragmentation and the structure of Amazonian liana communities Ecology, 21 (1) (2001), pp. 105-116

Lee D.L., Graham R. Leaf optical properties of rainforest sun and extreme shade plants American Journal of Botany, 73 (8) (1986), pp. 1100-1108

Lee D.W., Bone R.A., Tarsis S.L., Stroch D. Correlates of leaf optical properties in tropical forest sun and extremeshade plants American Journal of Botany, 77 (3) (1990), pp. 370-380

le Maire G., François C., Dufrêne Towards universal broad leaf chlorophyll indices using PROSPECT simulated database and hyperspectral reflectance measurements Remote Sensing of Environment, 89 (2004), pp. 1-28

Mahalanobis P.C. On the generalised distance in statistics Proceedings of the National Institute of Sciences of India, 2 (1) (1936), pp. 49-55

Mark S.N., Alberto S.A. Feature Extraction and Image Processing, Academic Press (2008), pp. 88-89

Mohan J.E., Ziska L.H., Schlesinger W.H., Thomas R.B., Sicher R.C., George K., et al. Biomass and toxicity responses of poison ivy (Toxicodendron radicans) to elevated atmospheric $\mathrm{CO}_{2}$ Proceedings of the National Academy of Sciences of the United States of America, 103 (24) (2006), pp. 9086-9089

Mohd-Shafri H.Z., Mohd-Salleh M.A., Ghiyamat A. Hyperspectral remote sensing of vegetation using red edge position techniques American Journal of Applied Sciences, 3 (6) (2006), pp. 1864-1871

Parker G.G., Smith A.P., Hogan K.P. Access to the upper forest canopy with a large tower crane Bioscience, 42 (9) (1992), pp. 664-670

Penuelas J., Filella I., Biel C., Serrano L., Save R. The reflectance at the $950-970 \mathrm{~nm}$ region as an indicator of plant water status International Journal of Remote Sensing, 14 (1993), pp. 1887-1905

Pérez-Salicrup D.R., de Meijere W. Number of lianas per tree and number of trees climbed by lianas at Los Tuxtlas, Mexico Biotropica, 37 (2005), pp. 153-156

Phillips O.L., Martinez R.V., Arroyo L., Baker T.R., Killeen T., Lewis S.L., et al. Increasing dominance of large lianas in Amazonian forests Nature, 418 (6899) (2002), pp. 770-774

Phillips O.L., Martinez R.V., Mendoza A.M., Baker T.R., Vargas P.N. Large lianas as hyperdynamic elements of the tropical forest canopy Ecology, 86 (5) (2005), pp. 1250-1258

Putz F.E. Liana biomass and leaf area of a Tierra Firme Forest in the Rio-Negro Basin, Venezuela Biotropica, 15 (1983), pp. 185-189

Putz P.E. The Natural history of lianas on Barro-Colorado Island, Panama Ecology, 65 (6) (1984), pp. 1713-1724

Putz P.E., Windsor D.M. Liana phenology on Barro Colorado Island, Panama Biotropica, 19 (4) (1987), pp. 334341

Pooter H., De Jong R. A comparison of specific leaf area, chemical composition and leaf construction costs of field plans from 15 habitats differing in productivity New Phytologist, 143 (1) (1999), pp. 163-176

Reich P.B., Walters M.B., Ellsworth D.S., Vose J.M., Volin J.C., Gresham C., et al. Relationships of leaf dark respiration to leaf nitrogen, specific leaf area and leaf life-span, a test across biomes and functional groups Oecologia, 114 (1998), pp. 471-482

Richards J.E. Chemical characterization of plant tissue. p115-139 M.R. Carter (Ed.), Soil Sampling and Methods of Analysis, CSSS. Lewis Publisher (1993), pp. 115-117

Richards J.E. Chemical characterization of plant tissue.p115-139 M.R. Carter (Ed.), Soil Sampling and Methods of Analysis, CSSS. Lewis Publisher (1993), pp. 121-123

Richards J.A. Remote Sensing Digital Image Analysis, An Introduction Springer (2005) 
Richardson A.D., Duigan S.P., Berlyn G.P. An evaluation of noninvasive methods to estimate foliar chlorophyll content New Phytologist, 153 (2002), pp. 185-194

Rivard B., Feng J., Gallie A., Sanchez-Azofiefa G.A. Continuous wavelets for the improved use of spectral libraries and hyperspectral data Remote Sensing of Environment, 112 (2008), pp. 2850-2862

Roberts D.A., Nelson B.W., Adams J.B., Palmar F. Spectral changes with leaf aging in Amazon caatinga Trees: Structure and Function, 12 (6) (1998), pp. 1432-2285

Shapiro L.G., Stockman G.C. Computer Vision, Prentence Hall (2001), pp. 137-150 Sánchez-Azofeifa G.A., CastroEsau K.L.Canopy observations on the hyperspectral properties of a community of tropical dry forest lianas and their host trees International Journal of Remote Sensing, 27 (10) (2006), pp. 2101-2109

Schnitzer S.A. A mechanistic explanation for global patters of liana abundance and distribution American Naturalist, 166 (2) (2005), pp. 262-276

Schnitzer S.A., Bongers F. The ecology of lianas and their role in forests Trends in Ecology and Evolution, 17 (5) (2002), pp. 223-230

Sims D.A., Gamon J.A. Relationships between leaf pigment content and spectral reflectance across a wide range of species, leaf structures and developmental stages Remote Sensing of Environment, 81 (2002), pp. 337-354

Slaton M.R., Hunt E.R. Jr., Smith W.K. Estimating near-infrared leaf reflectance from leaf structural characteristics American Journal of Botany, 88 (2001), pp. 278-284

Wright I.J., Reich P.B., Westoby M. Strategy-shifts in leaf physiology, structure and nutrient content between species of high and low rainfall, and high and low nutrient habitats Funtional Ecology, 15 (2001), pp. 423-434

Wright I.J., Westoby M. Differences in seedling growth behaviour among species: trait correlations across species, and trait shifts along nutrient compared to rainfall gradients Journal of Ecology, 87 (1) (1999), pp. 85-97

Wright S.J., Calderón O. Seasonal, El Niño and longer term changes in flower and seed production in a moist tropical forest Ecology Letters, 9 (2006), pp. 35-44

Wright S.J., Calderón O., Hernandéz A., Paton S. Are lianas increasing in importance in tropical forests? A 17-year record from Barro Colorado Island, Panamá Ecology, 85 (2004), pp. 484-489

Zhang J., Rivard B., Sánchez-Azofeifa G.A., Castro-Esau K.L. Intra and inter-class spectral variability of tropical tree species at La Selva, Costa Rica: implications for species identification using HYDICE imagery Remote Sensing of Environment, 105 (2) (2006), pp. 121-141

Zotz G., Winter K. Daily patterns of $\mathrm{CO}_{2}$ exchange in rainforest canopy plants S.S. Mulkeym, R.L. Chazdon, A.P. Smith (Eds.), Tropical forest plant ecophysiology, Chapman \& Hall, New York (1996), pp. 8-113 